\title{
Theoretical Study of the Adsorption of the Butanol Isomers in H-ZSM-5
}

\author{
Cuong M. Nguyen, Marie-Françoise Reyniers, ${ }^{*}$ and Guy B. Marin \\ Laboratory for Chemical Technology, Ghent University, Krijgslaan 281 S5, B-9000 Gent, Belgium \\ Supporting Information
}

\begin{abstract}
The adsorption of the four butanol isomers (1-BuOH, $\mathrm{i}-\mathrm{BuOH}, 2-\mathrm{BuOH}$, and $\mathrm{t}-\mathrm{BuOH})$ at the $\mathrm{Al} 12-\mathrm{O} 24-$ $(\mathrm{H})-\mathrm{Si} 12$ intersection site in H-ZSM-5 is investigated using the periodic [DFT-D] approach in which a damped interatomic potential (D) is included within the periodic density functional theory (pbcDFT) calculations to account for dispersive van der

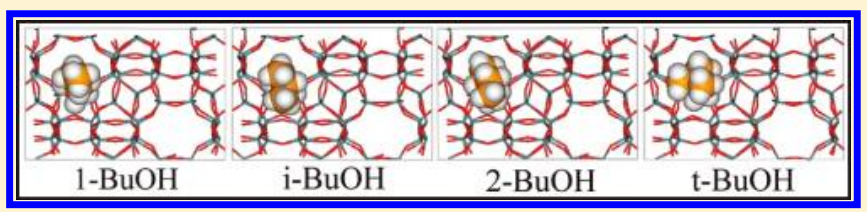
Waals (vdW) interactions. Both the pbcDFT and pbc[DFT-D] methods yield largely similar results for the geometry of adsorbed complexes. The pbc[DFT-D] adsorption energies of the butanols are similar to those obtained using the pbcDFT with an add-on single-point dispersion-energy correction ( $\mathrm{pbcDFT}+\mathrm{D})$. The adsorption strength of butanols decreases in the following order: $1-\mathrm{BuOH}\left(-160\right.$ to $\left.-164 \mathrm{~kJ} \mathrm{~mol}^{-1}\right)>2-\mathrm{BuOH}\left(-155\right.$ to $\left.-157 \mathrm{~kJ} \mathrm{~mol}^{-1}\right)>\mathrm{t}-\mathrm{BuOH}\left(-151 \mathrm{~kJ} \mathrm{~mol}^{-1}\right)>\mathrm{i}-\mathrm{BuOH}\left(-147 \mathrm{~kJ} \mathrm{~mol}{ }^{-1}\right)$. On the basis of a partial Hessian vibration analysis of the most stable physisorbed and chemisorbed complexes, reported experimental infrared (IR) spectra could be interpreted by assuming an equilibrium between physisorbed and chemisorbed minima on a flat potential energy surface. The extent to which the zeolite proton is transferred upon physisorption of the butanols increases from $1-\mathrm{BuOH}$ to $\mathrm{t}-\mathrm{BuOH}$ in agreement with an increase of the proton affinity of the alcohols. At the straight channel, the hydrogen bond strength ranges from -73 to $-88 \mathrm{~kJ} \mathrm{~mol}^{-1}$ while at the zigzag channel, the hydrogen bond strength for $2-\mathrm{BuOH}(-91 \mathrm{~kJ}$ $\left.\mathrm{mol}^{-1}\right)$ is somewhat larger as compared to 1 - and $\mathrm{i}-\mathrm{BuOH}\left(-68\right.$ to $\left.-72 \mathrm{~kJ} \mathrm{~mol}^{-1}\right)$. Upon chemisorption, the four butoxonium ions experience similar Coulomb and hydrogen bonding interactions. Steric constraints and vdW interactions exerted by the zeolite frame are found to be the dominant factors in governing the adsorption strength of butanols in H-ZSM-5. At the straight channel, the steric constraints increase slightly by $+15 \mathrm{~kJ} \mathrm{~mol}^{-1}$ in going from $1-\mathrm{BuOH}$ to $\mathrm{t}-\mathrm{BuOH}$ while in the zigzag channel a remarkably more pronounced increase of $+63 \mathrm{~kJ} \mathrm{~mol}^{-1}$ is observed. Neither for physisorption nor for chemisorption of $\mathrm{i}-\mathrm{BuOH}$ and $\mathrm{t}-\mathrm{BuOH}$, there is an energetic preference for one of the channels because in both channels vdW interactions counterbalance steric constraints. In contrast, for 1-BuOH and 2- $\mathrm{BuOH} v \mathrm{vW}$ interactions prevail leading to an energetic preference of some $11-14 \mathrm{~kJ} \mathrm{~mol}^{-1}$ for both physisorption and chemisorption in the zigzag channel. Accounting for the formation enthalpy of the gas-phase butanols, the stability of the adsorbed complexes of $\mathrm{t}-\mathrm{BuOH}$ and $2-\mathrm{BuOH}$ is predicted to be some $15-20 \mathrm{~kJ} \mathrm{~mol}^{-1}$ higher than those of $1-\mathrm{BuOH}$ and $\mathrm{i}-\mathrm{BuOH}$.
\end{abstract}

\section{INTRODUCTION}

Zeolites are among the most important industrial catalysts. The unique character of zeolitic molecular sieves originates from the uniform distribution of the active sites, Brønsted acid sites (BASs), in their micropores and cavities. ${ }^{1}$ The catalytic behavior of the zeolite is therefore dependent both on the acidity and on the geometry and dimension of the zeolite framework, which govern the diffusion, sorption/desorption of both reactants and products inside the zeolite. ${ }^{2}$ The reaction kinetics and product distribution are thus controlled by the whole zeolite framework to a significant extent. ${ }^{2}$ Therefore, it is important to obtain more insight into the effect of the zeolite framework on reaction kinetics and thermodynamics.

Of increased recent interest is the conversion of renewable biomass-derived alcohols into gasoline, biofuels, and biochemicals to reduce society's dependence on fossil fuel. ${ }^{3-5}$ To improve the efficiency of zeolite-catalyzed alcohol conversion processes, insight into the detailed reaction mechanism as well as accurate thermodynamic and kinetic parameters of the elementary reactions is of crucial importance. Up to date, however, detailed mechanistic studies of the intrazeolitic conversion of alcohols are still largely lacking and the elucidation of the reaction mechanism from experimental data only is extremely difficult. One of the main topics of debate is centered on the nature and stability of alcohol-zeolite adsorption complexes that are initially formed over the BASs in alcohol conversion processes. ${ }^{6-17}$ Physisorbed and chemisorbed complexes are both stabilized by hydrogen bonding (HB) interactions (Figure 1) and differ in the extent to which the zeolite acid proton has been transferred to the alcohol.

A limited number of both experimental and theoretical works have indicated that in addition to acidity, also pore structure and dimensions of the zeolite are important factors in controlling the nature and stability of alcohol-zeolite complexes. ${ }^{18-22}$ The effect of the zeolite framework is rather complicated and is executed through steric constraints and/or dispersive vdW

\footnotetext{
Received: December 9, 2010

Revised: March 22, 2011

Published: April 11, 2011
} 


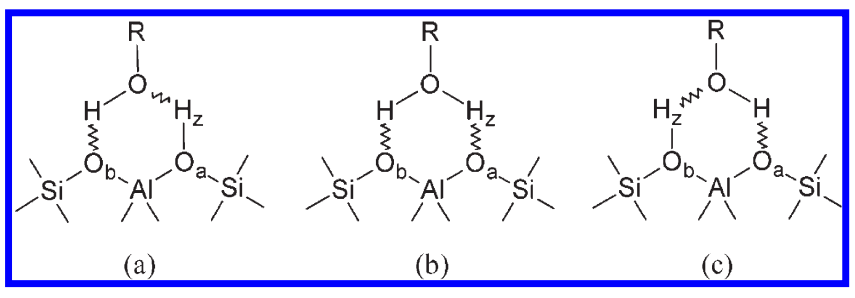

Figure 1. Alcohol-zeolite interaction. Hydrogen bonded physisorbed $(\mathrm{a}, \mathrm{c})$ and protonated chemisorbed complex $(\mathrm{b})$ over the Brønsted acid site (BAS). $\mathrm{H}_{z}$, zeolite proton; $\mathrm{O}_{a}, \mathrm{O}_{24}$; $\mathrm{O}_{\mathrm{b}}, \mathrm{O} 20$; and $\mathrm{Al}, \mathrm{Al} 12$.

interactions. ${ }^{23}$ In a comprehensive first principles molecular dynamics (MD) study of methanol adsorbed in several different zeolites, Stich et al. ${ }^{24}$ suggested that the proton transfer is strongly correlated with steric constraints and vdW interactions exerted by the zeolite framework. There is a noticeable increase in the fraction of chemisorbed methanol with decreasing channel diameter of the zeolite framework. Unfortunately, no quantitative correlation was found between the methanol adsorption energy and the dimension of these zeolite frameworks. ${ }^{21,24}$ Very recently, Nguyen et al. ${ }^{25}$ employed periodic density functional theory with a single-point dispersion-energy correction $(\mathrm{pbcDFT}+\mathrm{D})$ to study the adsorption of C1-C4 primary alcohols in H-ZSM-5. The $\mathrm{vdW}$ interactions due to the zeolite frame are found to contribute significantly to the adsorption energies of the alcohols and increase linearly with ca. $15 \mathrm{~kJ} \mathrm{~mol}^{-1}$ per carbon atom, ${ }^{25}$ which is in agreement with experimental result. ${ }^{26}$

To elucidate the influence of shape selectivity and pore structure of H-ZSM-5 on the adsorption and dehydration kinetics of the four butanols, Zamaraev et al. ${ }^{27-31}$ carried out a series of experimental studies using a combination of in situ FTIR spectroscopy and gas chromatography. The IR spectra of the adsorbed alcohols are characterized by two broad $\mathrm{OH}$ bands at $2400-2450$ and $1500-1600 \mathrm{~cm}^{-1}$, which are involved in strong hydrogen-bonding complexes. ${ }^{27-31}$ However, whether these complexes are physisorbed or chemisorbed over the BAS of H-ZSM-5 remains unclear in the works by Zamaraev et al. ${ }^{27-31}$ Note that the highest frequency OH bands at $3500-3700 \mathrm{~cm}^{-1}$ are reported for i-BuOH-H-ZSM- $5^{30}$ and $\mathrm{t}-\mathrm{BuOH}-\mathrm{HZSM}-5^{31}$ only. Interpretation of the IR spectra of absorbed butanols is hampered due to their fast dehydration to the corresponding butenes. ${ }^{27-31}$ In particular, upon adsorption of $2-\mathrm{BuOH}^{28}$ and $\mathrm{t}-\mathrm{BuOH},{ }^{31}$ dehydration can be expected to proceed even at moderate temperatures and the concomitant formation of adsorbed water, characterized by one bending at $1640 \mathrm{~cm}^{-1}$ and one stretching at $3700 \mathrm{~cm}^{-1}$, complicates the assignment of frequencies in these regions. To complement the aforementioned experimental works, Zamaraev et al. ${ }^{32}$ performed simulations of the adsorption of the four butanols in H-ZSM-5 and silicalite, using an molecular mechanics energy minimization procedure supplemented by a Monte Carlo/molecular dynamic (MC/MD) algorithm to assist in the location of minima. At a number of different crystallographic positions, adsorption energies of the four butanols ranging from -114 to -132 in H-ZSM-5 and from -120 to $-138 \mathrm{~kJ} \mathrm{~mol}^{-1}$ in silicalite were obtained. Also, the $\mathrm{O}_{\mathrm{a}}-\mathrm{H}_{z}$ bond length in H-ZSM-5 was found to remain unchanged upon adsorption of the butanols, indicating no specific interaction ( $\mathrm{HB}$ and/or Coulomb) between the butanols and the BAS. ${ }^{32}$ Clearly, these results indicate that the energy minimization procedure supplemented by a $\mathrm{MC} / \mathrm{MD}$ algorithm is less suited to provide an accurate description of alcohol adsorption in zeolites where both bonded and dispersive $\mathrm{vdW}$ interactions play important stabilizing roles.

As an extension of our previous pbcDFT $+\mathrm{D}$ study on $\mathrm{C} 1-\mathrm{C} 4$ primary alcohols, ${ }^{25}$ the present work investigates the effect of the pore dimensions of H-ZSM-5 on the energetics of adsorption of the four butanol isomers, that is, $1-\mathrm{BuOH}, \mathrm{i}-\mathrm{BuOH}$, $2-\mathrm{BuOH}$, and $\mathrm{t}-\mathrm{BuOH}$. These alcohols are ideally suited to examine the H-ZSM-5 framework effects since (1) their dimensions are comparable to those of the H-ZSM-5 channels and (2) their hydrocarbon skeletons with different branching present a convenient testing group to explore the role of the molecular shape and structure in controlling the nature and stability of the adsorbed complexes. Because of the dominant stabilizing role of $\mathrm{vdW}$ interactions, the $\mathrm{pbc}[\mathrm{DFT}-\mathrm{D}]$ approach $^{33,34}$ in which the Grimme's dispersion correction ${ }^{33}$ is included in the periodic DFT calculations ${ }^{34}$ is used in the present work for obtaining optimized structures, energies, and for determining harmonic vibrational frequencies of the adsorbed systems.

\section{MODELS AND METHODS}

2.1. Silicalite and H-ZSM-5 Models. Orthorhombic H-ZSM$5\left(\mathrm{HAlSi}_{95} \mathrm{O}_{192}\right)$ and its siliceous analogue silicalite $\left(\mathrm{Si}_{96} \mathrm{O}_{192}\right)$ unit cells ${ }^{25}$ are utilized as adsorbents for the docking of the four butanols. The orthorhombic ZSM-5 unit cell has 12 crystallographically distinguishable tetrahedral framework sites (T sites) for $\mathrm{Si} / \mathrm{Al}$ substitution. Experimental works ${ }^{35,36}$ show a variability of the $\mathrm{Al}$ siting for $\mathrm{ZSM}-5$ samples with the $\mathrm{Si} / \mathrm{Al}$ ratio of 95 (one $\mathrm{Al}$ per unit cell). However, performing calculations for adsorption of the four butanols on all the different possible $\mathrm{T}$ sites is computationally very expensive and practically unfeasible. Besides, previous theoretical calculations report small differences in energy among structures with $\mathrm{Al}$ at different $\mathrm{T}$ sites. ${ }^{37,38}$ For ZSM-5 samples with low $\mathrm{Si} / \mathrm{Al}$ ratios $(\mathrm{Si} / \mathrm{Al}<45)$, that is, more than $2 \mathrm{Al}$ per unit cell, the distribution of aluminum atoms exhibits insignificant effect on the acid strength of the zeolites. ${ }^{39}$ Therefore, we select the "intersection" site Al12-O24(H) - Si12 to represent the Brønsted acid site because it is considered among the most stable sites for $\mathrm{Al}$ substitution ${ }^{38,40,41}$ and has been chosen as the active site for several reactions. ${ }^{24,25,41-43}$ Moreover, the intersection site provides maximum reaction space and easy access for reactants, especially bulky ones. ${ }^{43,44}$ Considering the proton jump among the adjacent Al-bound oxygen atoms at the T-12 site, Svelle et al., ${ }^{22}$ and Nguyen et al. ${ }^{25}$ found a energetic preference of $5-12 \mathrm{~kJ} \mathrm{~mol}^{-1}$ for the location of zeolite proton at the $\mathrm{Al} 12-\mathrm{O} 20(\mathrm{H})-\mathrm{Si} 3$ as compared with the Al12-O24(H)-Sil2 bridging site. However, Nguyen et al. ${ }^{25}$ have shown that the location of the zeolite proton at either of the two sites has no significant effect on the adsorption energy of alcohols. $^{22,25}$

Structural parameters and graphical illustrations of the optimized silicalite and H-ZSM-5 unit cells are presented in our previous work. ${ }^{25}$ In the present study, the notations $\mathrm{O}_{b} \mathrm{Al}\left[\mathrm{O}_{\mathrm{a}} \mathrm{H}_{\mathrm{z}}\right]$ and $\mathrm{O}_{\mathrm{a}} \mathrm{Al}\left[\mathrm{O}_{\mathrm{b}} \mathrm{H}_{\mathrm{z}}\right]$ are used to indicate the location of the zeolite proton $\left(\mathrm{H}_{\mathrm{z}}\right)$ at $\mathrm{O} 24\left(\mathrm{O}_{\mathrm{a}}\right)$ and $\mathrm{O} 20\left(\mathrm{O}_{\mathrm{b}}\right)$ of the Al12 site, respectively (Figure 1). Geometries of the representative $\mathrm{i}-\mathrm{BuOH}$-silicalite physisorbed complexes as well as i-BuOH-H-ZSM-5 physisorbed and chemisorbed complexes over the intersection site $\mathrm{O}_{\mathrm{b}} \mathrm{Al}\left[\mathrm{O}_{\mathrm{a}} \mathrm{H}_{\mathrm{z}}\right]$ are illustrated in Figures 2-4. Those of the other butanols are given in the Supporting Information (S.1-S.3).

In addition, BuOH-HZSM-5 physisorbed complexes are sampled at the other $\mathrm{BAS} \mathrm{O}_{\mathrm{a}} \mathrm{Al}\left[\mathrm{O}_{\mathrm{b}} \mathrm{H}_{\mathrm{z}}\right]$ with the zeolite proton 


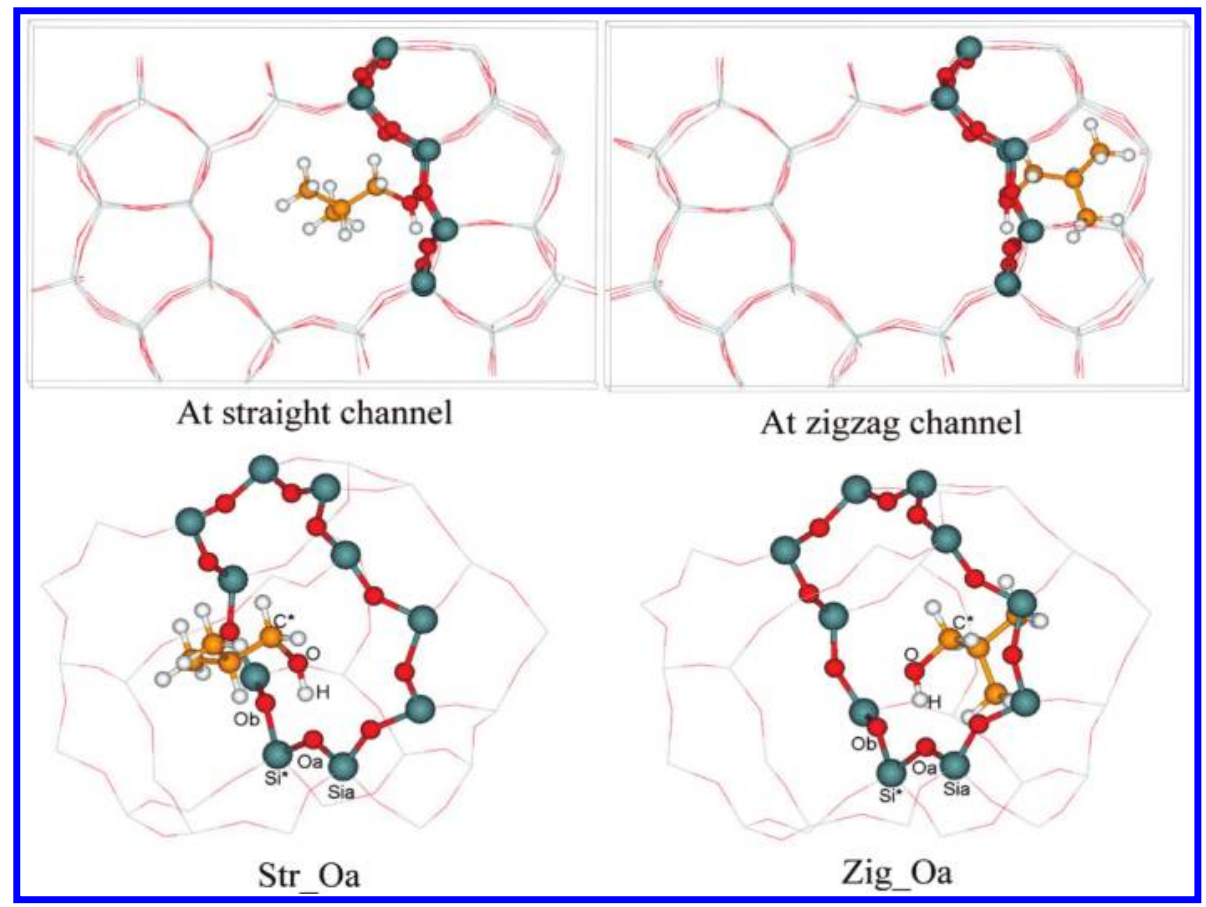

Figure 2. Representative silicalite- $\mathrm{BuOH}$ physisorbed complexes. $\mathrm{i}-\mathrm{C}_{4} \mathrm{H}_{9} \mathrm{OH}$ physisorption at the straight and zigzag channels viewed in the [010] direction (top panels). Highlighted atoms define the 10-T intercrossing ring between the two channels. $\mathrm{Si}^{*}-\mathrm{O}_{\mathrm{a}}-\mathrm{Si}_{\mathrm{a}}$ indicates the $\mathrm{T} 12$ bridging position $\mathrm{Si} 12-\mathrm{O} 24-\mathrm{Si} 12$ for $\mathrm{Al}$ substitution at $\mathrm{Si}^{*}$ with $\mathrm{Si}^{*}=\mathrm{Si} 12, \mathrm{O}_{\mathrm{a}}=\mathrm{O} 24, \mathrm{Si}_{\mathrm{a}}=\mathrm{Si} 12$, respectively. The intersection space between two channels (top pannel) is divided into two parts by the 10-T ring; the left part belongs to the straight channel while the right part belongs two the zigzag channel. The i-BuOH molecule has the $\mathrm{H}$ atom pointed to $\mathrm{O}_{\mathrm{a}}$ and the hydrocarbon chain accommodated at the straight $\left(\right.$ Str__ $\left.\mathrm{O}_{\mathrm{a}}\right)$ or zigzag channel $\left(\mathrm{Zig} \_\mathrm{O}\right.$ ). Code colors used: oxygen (red), silicon (gray), hydrogen (white), and carbon (yellow).

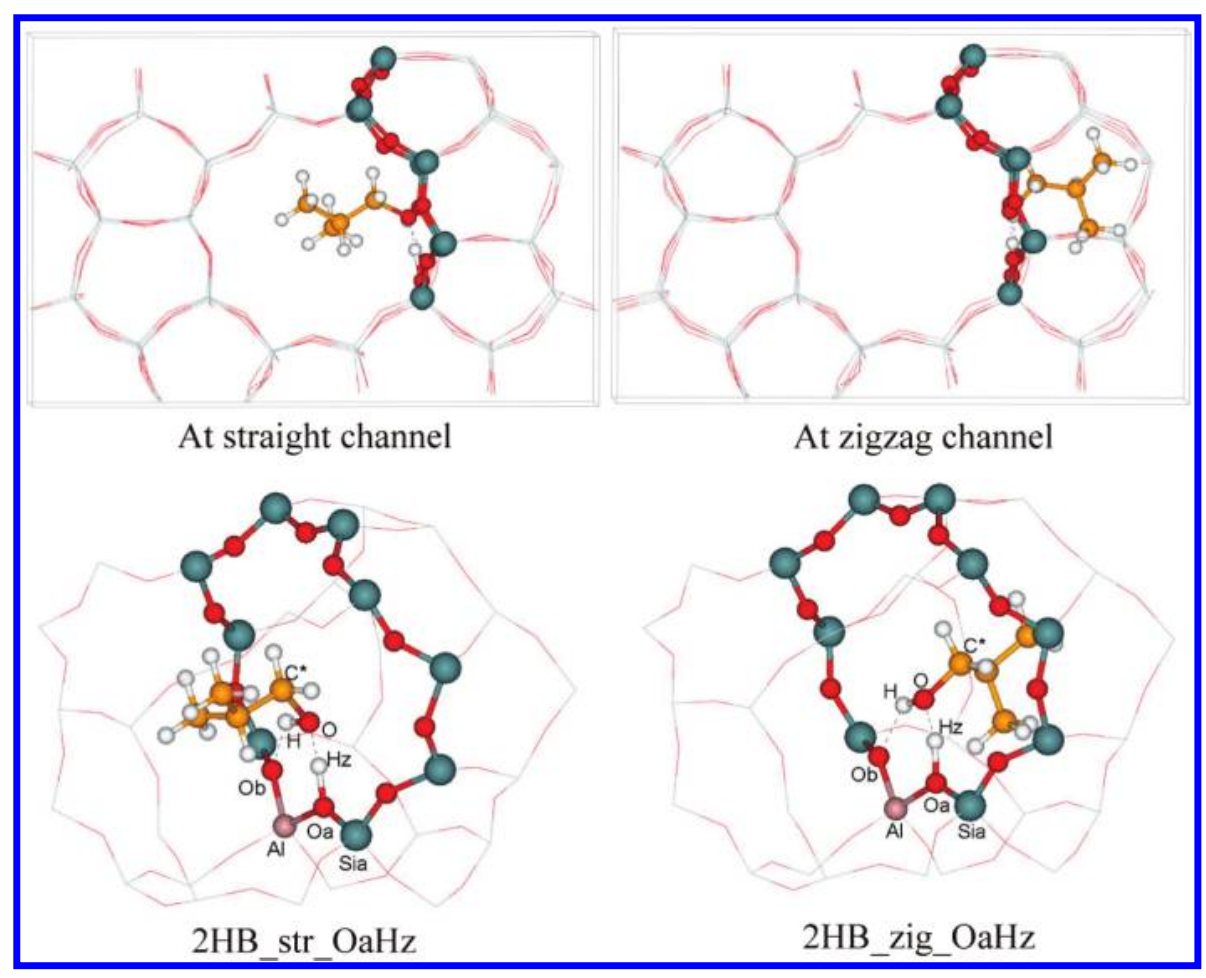

Figure 3. Representative $\mathrm{H}-\mathrm{ZSM}-5-\mathrm{BuOH}$ physisorbed complexes at the $\mathrm{O}_{\mathrm{b}} \mathrm{Al}\left[\mathrm{O}_{\mathrm{a}} \mathrm{H}_{\mathrm{z}}\right]$. i-BuOH physisorption at the straight (str) and zigzag (zig) channels viewed in the [010] direction (top pannels). Highlighted atoms define the 10-T intercrossing ring between the two channels. $\mathrm{Si}_{\mathrm{a}}=\mathrm{Si1}_{\mathrm{i}}, \mathrm{O}_{\mathrm{a}}=$ $\mathrm{O} 24, \mathrm{Al}=\mathrm{Al12}$, and $\mathrm{O}_{\mathrm{b}}=\mathrm{O} 20$. The alcohol molecule interacts with the BAS via two hydrogen bonds $\mathrm{O}---\mathrm{H}_{\mathrm{z}}$ and $\mathrm{O}_{\mathrm{b}}---\mathrm{H}\left(2 \mathrm{HB} \_\right.$str_O $\mathrm{O}_{\mathrm{a}} \mathrm{H}_{\mathrm{z}}$ and 2HB_zig_O $\mathrm{O}_{\mathrm{a}} \mathrm{H}_{\mathrm{z}}$ ). Code colors used: aluminum (pink), oxygen (red), silicon (gray), hydrogen (white), carbon (yellow). 


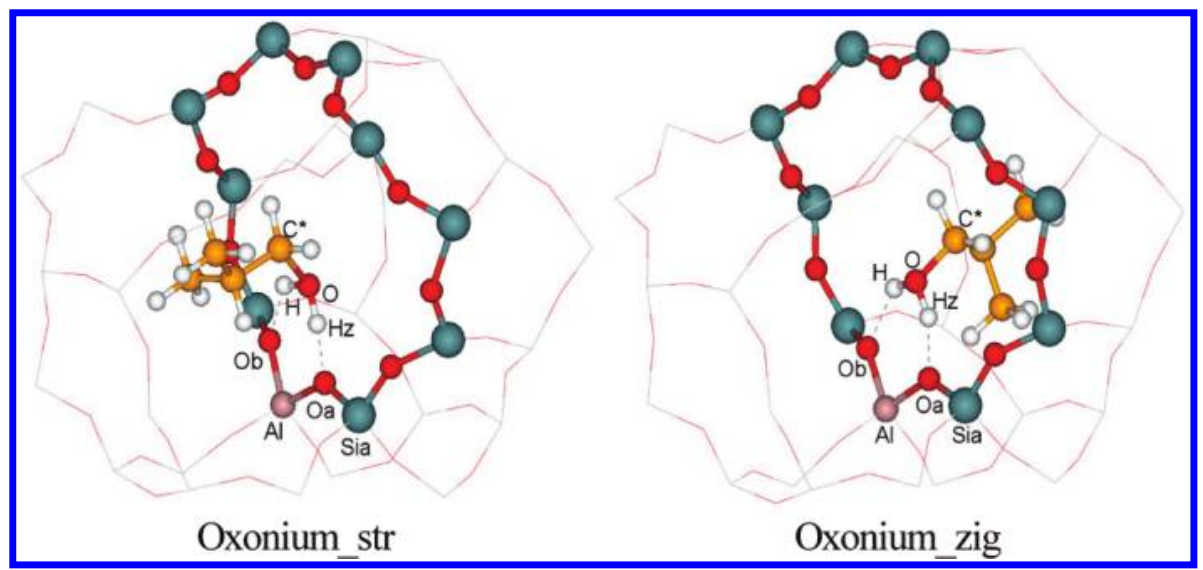

Figure 4. Representative H-ZSM-5-i-BuOH chemisorbed complexes. Oxonium_str at the straight channel and Oxonium_zig at the zigzag channel.

attached to $\mathrm{O}_{\mathrm{b}}$. For all butanols except 2-BuOH at the zigzag channel, the location of the zeolite proton $\left(\mathrm{H}_{\mathrm{z}}\right)$ at $\mathrm{O}_{\mathrm{a}}$ or $\mathrm{O}_{\mathrm{b}}$ has no significant effect on the structural parameters and energetics of the physisorbed complexes. Detailed geometrical parameters and physisorption energies of the butanols over the BAS $\mathrm{O}_{\mathrm{a}} \mathrm{Al}-$ $\left[\mathrm{O}_{\mathrm{b}} \mathrm{H}_{\mathrm{z}}\right]$ are presented in the Supporting Information (S.4).

2.2. Computational Methods. In this study, both the pbcDFT and $\mathrm{pbc}[\mathrm{DFT}-\mathrm{D}]^{33,34}$ approaches were utilized for obtaining optimized structures, energies of the four butanols adsorbed in silicalite and H-ZSM-5. Harmonic vibrational modes of gas-phase alcohols, unloaded H-ZSM-5, and adsorption complexes were calculated. For periodic structures, Partial Hessian Vibrational Analysis (PHVA) was performed for only $\mathrm{AlO}_{3} \mathrm{OH}$ and four $\mathrm{Al}-$ bound adjacent $\mathrm{SiO}_{4}$ tetrahedral groups in addition to the adsorbate (in the case of adsorbed complexes) to avoid the computational cost for the whole systems of up to 304 atoms. For gas-phase alcohols, the full Hessian was calculated. Bader charge analysis ${ }^{45}$ was utilized to calculate formal charge of adsorbed fragments.

Also, optimized geometries obtained using the pbcDFT level of theory were subject to a single-point dispersion-energy correction calculation $(\mathrm{pbcDFT}+\mathrm{D})$ to pragmatically account for the contribution of dispersive vdW interactions to the total adsorption energy of alcohols. The dispersion-corrected energies obtained using both the pbcDFT $+\mathrm{D}$ and pbc[DFT-D] approaches were then compared.

Physisorption or chemisorption energy $\left(\Delta E_{\text {phys }}\right.$ or $\Delta E_{\text {chem }}$, respectively) of an alcohol in silicalite/H-ZSM-5 is computed relative to the unloaded silicalite/H-ZSM-5 and the corresponding gas phase alcohol at $0 \mathrm{~K}$. The proton transfer energy, $\Delta E_{\mathrm{pt}}$ is defined as the dispersion-corrected energy difference between chemisorbed and physisorbed complex.

The effect of the $\mathrm{O}-\mathrm{H}$ bond length variation on the energy and on the harmonic stretching frequencies of the $\mathrm{H}_{\mathrm{z}}-\mathrm{O}-\mathrm{H}$ group of the chemisorbed complexes was inspected for $1-\mathrm{BuOH}$ at the zigzag channel and for $\mathrm{t}-\mathrm{BuOH}$ at the straight channel.

2.2.1. pbcDFT Calculations. Periodic DFT calculations are performed using the Vienna Ab Initio Simulation Package (VASP) code. ${ }^{46}$ The Kohn-Sham equations were solved variationally using the projector-augmented wave (PAW) method ${ }^{47,48}$ and gradient-corrected Perdew-Burke-Ernzerhof (PBE) exchange-correlation functional. ${ }^{49}$ Brillouin zone sampling was restricted to the $\Gamma$ point. For the geometry optimization, a planewave cutoff of $400 \mathrm{eV}$ was employed and the convergence criterion for the electronic self-consistency loop was set to $10^{-5} \mathrm{eV}$.
Structures were considered converged when forces on all atoms dropped below $0.05 \mathrm{eV} / \AA$. . Tests of increasing plane-wave cutoff to $600 \mathrm{eV}$ and decreasing electronic threshold to $10^{-6} \mathrm{eV}$ proved that values used were sufficient to converge energy differences for alcohol-zeolite systems within $2 \mathrm{~kJ} \mathrm{~mol}^{-1}$. The force threshold of $0.05 \mathrm{eV} / \AA$ was verified to be sufficient to obtain reliable eigenfrequencies of alcohol-zeolite complexes.

2.2.2. $p b c[D F T-D]$ Calculations. The $\mathrm{pbc}[\mathrm{DFT}-\mathrm{D}]$ approach for periodic systems according to Kerber et al. ${ }^{33}$ using the Ewald summation technique ${ }^{50}$ was used to implement Grimme's dispersion correction ${ }^{34}$ within $\mathrm{VASP}^{46}$ for the zeolite. The total dispersion-corrected energy of a periodic system is thus defined as

$$
E_{\mathrm{DFT}-\mathrm{D}}=E_{\mathrm{DFT}}+E_{\mathrm{D}}
$$

where $E_{\mathrm{DFT}}$ is the self-consistent DFT Kohn-Sham electronic energy and $E_{\mathrm{D}}$ is the empirical dispersion energy. Calculation of the dispersion energy term for periodic systems involves the evaluation of lattice sums of the form

$$
E_{\mathrm{D}}=-\frac{s_{6}}{2} \sum_{L} \sum_{i, j \in L=0} \frac{\sqrt{c_{6}^{i} c_{6}^{i}}}{\left|r_{i j}-L\right|^{6}} f_{\mathrm{D}}\left(\left|r_{i j}-\mathbf{L}\right|\right)
$$

in which $s_{6}$ is the global scaling factor, 0.75 is for PBE functional, $\mathbf{L}$ is the direct lattice translation vector, $i$ and $j$ are the atoms within the central unit cell, $c_{6}^{i}$ denotes the atomic dispersion coefficients, and $f_{\mathrm{D}}$ is a damping function of interatomic distance $r_{i j}$. The sums over $i$ and $j$ go over all atoms inside the cell except that $i \neq j$ when $\mathbf{L}=0$. Detailed information over the calculation technique for the lattice sums of dispersion energy as well as the implementation of $\mathrm{pbc}[\mathrm{DFT}-\mathrm{D}]$ is outlined in the work by Kerber et al. $^{33}$ All the atomic parameters and the form of damping function are given by Grimme et al. ${ }^{34}$

A detailed comparison of the performance of pbcDFT $+\mathrm{D}$ versus $\mathrm{pbc}[\mathrm{DFT}-\mathrm{D}]$ with respect to geometries, adsorption energies and vibrational motions of the four butanols adsorbed in silicalite and H-ZSM-5 is presented in the Supporting Information (S.5). Both the pbcDFT and pbc[DFT-D] methods yielded largely similar results for the geometry optimization and PHVA analysis. As expected, the adsorption energies obtained using the pbcDFT are dramatically underestimated. Both the pbcDFT $+\mathrm{D}$ and pbc[DFT-D] approaches overcome this shortcoming of the pbcDFT. An agreement is observed between 
the two approaches for computing the DFT and D energy terms of the total dispersion-corrected adsorption energy.

The geometry optimization and energy calculation results show that both the pbcDFT $+\mathrm{D}$ and pbc[DFT-D] approaches offer an improvement to the pbcDFT approach in modeling the adsorption of alcohols in zeolite where the dispersive vdW interactions play a significant role in governing the stability of adsorbed complexes. Furthermore, together with the Hessian analysis and transition state finding algorithms integrated in VASP, the pbc[DFT-D] approach provides a comprehensive simulation methodology, that is, all geometrical, energetic, and energy derivative calculations are performed at the same level of pbc[DFT-D] theory, for both thermodynamic and kinetic study of chemical reactions in periodic structures such as zeolites. The following sections present a discussion of the structural effects of the MFI framework of silicalite and H-ZSM-5 on the adsorption of the four butanols according to $\mathrm{pbc}[\mathrm{DFT}-\mathrm{D}]$ results.

\section{RESULTS AND DISCUSSION}

3.1. Physisorption in Silicalite. 3.1.1. Geometry. Upon adsorption at both the straight and zigzag channels of silicalite,

Table 1. Geometrical Parameters $(\mathrm{pm})^{a}$ of Butanols Physisorbed in Silicalite Obtained Using the pbc[DFT-D] Approach

\begin{tabular}{|c|c|c|c|c|c|}
\hline & & \multicolumn{2}{|c|}{ gas-phase } & \multicolumn{2}{|c|}{ in silicalite } \\
\hline & & $\mathrm{H}-\mathrm{O}$ & $\mathrm{PA}^{b}$ & $\mathrm{H}-\mathrm{O}$ & $\mathrm{H}---\mathrm{O}_{\mathrm{a}}$ \\
\hline \multirow[t]{4}{*}{ straight channel } & $1-\mathrm{BuOH}$ & 97.3 & -834 & 97.4 & 214.1 \\
\hline & $\mathrm{i}-\mathrm{BuOH}$ & 97.2 & -836 & 97.6 & 216.2 \\
\hline & 2-BuOH & 97.4 & -849 & 97.4 & 228.5 \\
\hline & $\mathrm{t}-\mathrm{BuOH}$ & 97.5 & -860 & 97.6 & 214.4 \\
\hline \multirow[t]{4}{*}{ zigzag channel } & 1-BuOH & & & 97.4 & 226.8 \\
\hline & $\mathrm{i}-\mathrm{BuOH}$ & & & 97.5 & 238.2 \\
\hline & 2-BuOH & & & 97.6 & 210.7 \\
\hline & $\mathrm{t}-\mathrm{BuOH}$ & & & 97.6 & 210.9 \\
\hline
\end{tabular}

${ }^{a}$ Atom labels are defined in Figure 2. ${ }^{b}$ Gas-phase proton affinities at $0 \mathrm{~K}$ (PA, kJ mol ${ }^{-1}$ ) of butanols were measured using Gaussian at the CBSQB3 level of theory. there are no significant changes in structure of the alcohols, namely, the alcohol $\mathrm{OH}$ bond is elongated by only $0.0-0.4 \mathrm{pm}$ (Table 1), which is in agreement with the observation for the $\mathrm{C} 1-\mathrm{C} 4$ primary alcohols physisorbed in silicalite using the pbcDFT for geometry optimization. ${ }^{25}$ The weak and nonspecific interaction between one oxygen of the zeolite lattice $\left(\mathrm{O}_{\mathrm{a}}\right)$ and the hydroxyl hydrogen $(\mathrm{H})$ of the butanols (Figure 2) is clearly demonstrated by the long interatomic distances $\mathrm{d}\left[\mathrm{H}---\mathrm{O}_{\mathrm{a}}\right]$ of 210.7-238.2 pm.

3.1.2. Physisorption Energy. Table 2 presents physisorption energies of the four butanols. At the straight channel, all butanols have insignificantly different $\Delta E_{\text {DFT-D }}$ while a wider range of $\Delta E_{\mathrm{DFT}-\mathrm{D}}$ is observed at the zigzag channel. At both the channels, the $\mathrm{BuOH}$-silicalite complexes are mainly stabilized by the prevailing vdW dispersive interactions due to the surrounding silicalite lattice (see $\Delta E_{\mathrm{D}}$ and $\% \Delta E_{\mathrm{D}}$, Table 2).

Further analysis of $\Delta E_{\mathrm{DFT}}$ and $\Delta E_{\mathrm{D}}$ contributions allows the evaluation of the role of the molecular shape and structure in governing the physisorption strength of the butanols in silicalite. In going from $1-\mathrm{BuOH}$ to $\mathrm{t}-\mathrm{BuOH}$, the $\Delta E_{\mathrm{DFT}}$ strength decreases slightly from -14 to $1 \mathrm{~kJ} \mathrm{~mol}^{-1}$ at the straight channel, but more remarkably from -4 to $+59 \mathrm{kJmol}^{-1}$ at the zigzag channel (Table 2) indicating an increase in steric constraints with increasing branching level and bulkiness of the hydrocarbon chain. Taking 1-BuOH as a reference, the destabilization due to steric constraints at the straight or zigzag channel, $E_{\text {strain }}$ upon adsorption of another butanol can be estimated as the difference in their $\Delta E_{\mathrm{DFT}}$ (see $E_{\text {strain }}$, Table 2). The largest $E_{\text {strain }}$ of $+63 \mathrm{~kJ}$ $\mathrm{mol}^{-1}$ is estimated for adsorption of $\mathrm{t}-\mathrm{BuOH}$, the bulkiest butanol, at the zigzag channel. At the straight channel, the slight increase in $E_{\text {strain }}$ in going from $1-\mathrm{BuOH}$ to $\mathrm{t}-\mathrm{BuOH}$ is partly counteracted by a small increase in $\Delta E_{\mathrm{D}}$ resulting in largely similar $\Delta E_{\mathrm{DFT}-\mathrm{D}}$ of the four butanols. However, at the zigzag channel, the former factor prevails and renders the adsorption of $\mathrm{t}$-BuOH some $20-30 \mathrm{~kJ} \mathrm{~mol}^{-1}$ less energetically favorable than that of other butanols.

Table 3 presents the difference in adsorption energy computed between the two channels of silicalite $\left(\delta_{\mathrm{ch}}=\Delta E_{\text {phys }}^{\text {zigzag }}\right.$ $\Delta E_{\text {phys }}^{\text {straight }}$ ) and allows the evaluation of the pore dimension effect. According to $\delta_{\mathrm{ch}}\left[\Delta E_{\mathrm{DFT}-\mathrm{D}}\right]$, the zigzag channel is energetically somewhat more favorable than the straight channel for

Table 2. DFT-D, DFT, and D Physisorption Energies $\left(\Delta E_{\mathrm{phys}}, \mathrm{kJ} \mathrm{mol}^{-1}\right)$ of Butanols in Silicalite and H-ZSM-5 Obtained Using the pbc[DFT-D] Approach

\begin{tabular}{|c|c|c|c|c|c|c|c|c|c|c|c|c|c|}
\hline & & \multicolumn{4}{|c|}{ in silicalite } & \multirow[b]{2}{*}{$E_{\text {strain }}^{b}$} & \multirow[b]{2}{*}{$\Delta E_{\mathrm{MC} / \mathrm{MD}}{ }^{c}$} & \multicolumn{4}{|c|}{ in H-ZSM-5 } & \multirow[b]{2}{*}{$\Delta E_{\mathrm{MC} / \mathrm{MD}}{ }^{c}$} & \multirow[b]{2}{*}{$\delta\left[\Delta E_{\mathrm{DFT}}\right]^{d}$} \\
\hline & & $\Delta E_{\text {DFT-D }}$ & $\Delta E_{\mathrm{DFT}}$ & $\Delta E_{\mathrm{D}}$ & $\% \Delta E_{\mathrm{D}}$ & & & $\Delta E_{\text {DFT-D }}$ & $\Delta E_{\mathrm{DFT}}$ & $\Delta E_{\mathrm{D}}$ & $\% \Delta E_{\mathrm{D}}$ & & \\
\hline \multirow[t]{4}{*}{ straight channel } & 1-BuOH & -68 & -14 & -54 & 79 & 0 & $-116 /-117$ & -148 & -87 & -61 & 41 & $-115 /-120$ & -73 \\
\hline & $\mathrm{i}-\mathrm{BuOH}$ & -66 & -10 & -56 & 85 & +4 & $-109 /-121$ & -147 & -89 & -58 & 40 & -120 & -79 \\
\hline & 2-BuOH & -58 & -2 & -56 & 97 & +12 & $-106 /-112$ & -144 & -81 & -63 & 44 & $-113 /-127$ & -83 \\
\hline & $\mathrm{t}-\mathrm{BuOH}$ & -60 & 1 & -61 & 102 & +15 & $-110 /-114$ & -148 & -87 & -61 & 41 & $-117 /-124$ & -88 \\
\hline \multirow[t]{4}{*}{ zigzag channel } & 1-BuOH & -79 & -4 & -75 & 95 & 0 & $-117 /-132$ & -160 & -76 & -84 & 53 & $-120 /-138$ & -72 \\
\hline & $\mathrm{i}-\mathrm{BuOH}$ & -71 & 20 & -91 & 128 & +24 & $-108 /-120$ & -147 & -48 & -99 & 67 & $-115 /-119$ & -68 \\
\hline & 2-BuOH & -70 & 33 & -103 & 147 & +37 & $-100 /-118$ & -155 & -58 & -97 & 63 & $-109 /-127$ & -91 \\
\hline & $\mathrm{t}-\mathrm{BuOH}^{a}$ & -51 & 59 & -110 & 216 & +63 & $-109 /-114$ & & & & & $-111 /-129$ & \\
\hline
\end{tabular}

${ }^{a}$ Physisorbed complex of t-BuOH could not be located at the zigzag channel of $\mathrm{H}-\mathrm{ZSM}-5 .{ }^{b}$ Steric constraints energy $\left(E_{\text {strain }}\right)$ is calculated as the increase in $\Delta E_{\mathrm{DFT}}$ endothermicity of the other butanols relative to $1-\mathrm{BuOH}$ at each channel of silicalite. $E_{\text {strain }}$ of $1-\mathrm{BuOH}$ is assumed to be zero. ${ }^{c} \mathrm{Physisorption}$ energies $\left(\mathrm{kJ} \mathrm{mol}^{-1}\right)$ of butanols at different crystallographic positions in silicalite and in H-ZSM-5 obtained using the energy minimization procedure supplemented by a Monte Carlo/molecular dynamics (MC/MD) algorithm taken from ref $32 .{ }^{d} \delta\left[\Delta E_{\mathrm{DFT}}\right]=\Delta E_{\mathrm{DFT} / \mathrm{H}-\mathrm{ZSM}-5}-\Delta E_{\mathrm{DFT} / \text { silicalite }}$ used as a rough estimate of hydrogen bond strength between the butanol and the BAS of H-ZSM-5. 
Table 3. The Difference $\left(\delta_{\mathrm{ch}}, \mathrm{kJ} \mathrm{mol}^{-1}=\Delta E_{\mathrm{phys}}^{\text {zigzag }}-\Delta E_{\text {phys }}^{\text {straight }}\right)$ in Physisorption Energy Computed between the Zigzag and Straight Channel Obtained Using the pbc[DFT-D] Approach

\begin{tabular}{|c|c|c|c|c|c|c|}
\hline & \multicolumn{3}{|c|}{ in silicalite } & \multicolumn{3}{|c|}{ in H-ZSM-5 } \\
\hline & $\delta_{\mathrm{ch}}\left[\Delta E_{\mathrm{DFT}-\mathrm{D}}\right]$ & $\delta_{\mathrm{ch}}\left[\Delta E_{\mathrm{DFT}}\right]$ & $\delta_{\mathrm{ch}}\left[\Delta E_{\mathrm{D}}\right]$ & $\delta_{\mathrm{ch}}\left[\Delta E_{\text {DFT-D }}\right]$ & $\delta_{\mathrm{ch}}\left[\Delta E_{\mathrm{DFT}}\right]$ & $\delta_{\mathrm{ch}}\left[\Delta E_{\mathrm{D}}\right]$ \\
\hline 1-BuOH & -11 & +10 & -21 & -12 & +11 & -23 \\
\hline $\mathrm{i}-\mathrm{BuOH}$ & -6 & +30 & -36 & 0 & +41 & -41 \\
\hline 2-BuOH & -11 & +36 & -47 & -11 & +23 & -34 \\
\hline $\mathrm{t}-\mathrm{BuOH}^{a}$ & +9 & +58 & -49 & & & \\
\hline
\end{tabular}

Table 4. Geometrical Parameters (Distances in pm and Angles in Degrees) ${ }^{a}$ of Unloaded H-ZSM-5 and Physisorbed BuOH-HZSM-5 Complexes at the Straight and Zigzag Channels Using the pbc[DFT-D] Approach

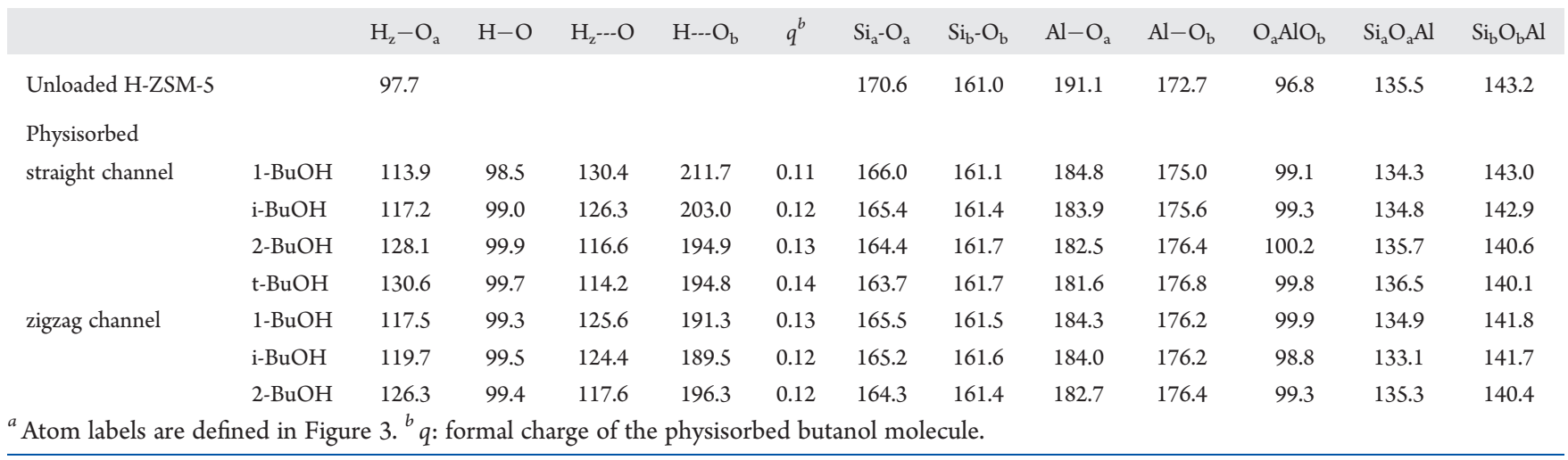

the adsorption of $1-\mathrm{BuOH}, \mathrm{i}-\mathrm{BOH}$, and $2-\mathrm{BuOH}$ owing to the predominance of the vdW interactions over the steric constraints $\left(\delta_{\mathrm{ch}}\left[\Delta E_{\mathrm{D}}\right]=-21\right.$ to $-47 \mathrm{~kJ} \mathrm{~mol}^{-1}$ versus $\delta_{\mathrm{ch}}\left[\Delta E_{\mathrm{DFT}}\right]=+10$ to + $36 \mathrm{~kJ} \mathrm{~mol}^{-1}$ ). Adsorption of the bulkiest $\mathrm{t}-\mathrm{BuOH}$ is, however, slightly preferred at the more extended straight channel since the former cannot counterbalance the latter factor $\left(\delta_{\mathrm{ch}}\left[\Delta E_{\mathrm{D}}\right]=-49\right.$ $\mathrm{kJ} \mathrm{mol}{ }^{-1}$ versus $\left.\delta_{\mathrm{ch}}\left[\Delta E_{\mathrm{DFT}}\right]=+58 \mathrm{~kJ} \mathrm{~mol}^{-1}\right)$. Taking the most stable physisorbed complex of each $\mathrm{BuOH}$, the DFT-D physisorption strength decreases in the order: $1-\mathrm{BuOH}(-79 \mathrm{~kJ}$ $\left.\mathrm{mol}^{-1}\right)>\mathrm{i}-\mathrm{BuOH}\left(-71 \mathrm{~kJ} \mathrm{~mol}^{-1}\right) \approx 2-\mathrm{BuOH}\left(-70 \mathrm{~kJ} \mathrm{~mol}^{-1}\right)$ $>\mathrm{t}-\mathrm{BuOH}\left(-60 \mathrm{~kJ} \mathrm{~mol}^{-1}\right)$.

3.2. Physisorption in H-ZSM-5. 3.2.1. Geometry. In contrast to the alcohol-silicalite complexes, all alcohol-H-ZSM-5 physisorbed complexes are characterized by two distinguishable HBs: a primary $\mathrm{H}_{\mathrm{z}}---\mathrm{O} \mathrm{HB}$ between the zeolite hydrogen and the oxygen of the alcohol and a secondary $\mathrm{H}---\mathrm{O}_{b} \mathrm{HB}$ between the alcohol hydrogen and the adjacent alumina-bound oxygen (Table 4). All the physisorbed butanols possess a small positive charge $(q)$ in the range +0.11 to +0.14 .

It is observed at both the straight and zigzag channels of H-ZSM-5 that the extent to which the zeolite proton $\mathrm{H}_{\mathrm{z}}$ is partially transferred to the alcohol molecule increases in going from $1-\mathrm{BuOH}$ over $\mathrm{i}-\mathrm{BuOH}$ to $2-\mathrm{BuOH}$ and $\mathrm{t}-\mathrm{BuOH}$ as clearly evidenced by the increase in $\mathrm{H}_{\mathrm{z}}-\mathrm{O}_{\mathrm{a}}$ bond length and the decrease in $\mathrm{H}_{\mathrm{z}}--\mathrm{O}$ distance (Table 4). Further, the 2-HB physisorbed complex of $\mathrm{t}-\mathrm{BuOH}$ could not be located at the zigzag channel; all geometrical optimizations starting from a physisorbed or a chemisorbed initial geometry relaxed to the protonated oxonium as the local minimum. A first principles molecular dynamic study of methanol adsorption in several zeolite frameworks ${ }^{24}$ showed that there is a noticeable increase in the fraction of chemisorbed methanol with decreasing free space available for relaxation of the adsorbed methanol molecule. Therefore, it is probable that the confined zigzag channel is not preferable for the formation of 2-HB physisorbed complex of the bulky $\mathrm{t}-\mathrm{BuOH}$. Upon physisorption of the butanols, changes of other structural parameters of the H-ZSM-5 framework are also induced at both the channels (Table 4). It is interesting to note that the extent of these framework distortions in going from $1-\mathrm{BuOH}$ to $\mathrm{t}-\mathrm{BuOH}$ parallels the extent of partial proton transfer as discussed above.

The marked differences in $\mathrm{d}\left[\mathrm{H}_{\mathrm{z}}-\mathrm{O}_{\mathrm{a}}\right]$ and $\mathrm{d}\left[\mathrm{H}_{\mathrm{z}}---\mathrm{O}\right]$ observed between $1-\mathrm{BuOH}$ and $\mathrm{t}-\mathrm{BuOH}$ at the straight channel may be ascribed to the intrinsic basicity of the alcohol, measured by its gas phase proton affinity (PA). Because of the discrepancy among the reported PA values for the butanols in literature (see Supporting Information S6), ${ }^{51-55}$ PAs of the four $\mathrm{BuOH}$ isomers were calculated at the CBS-QB3 level of theory using Gaussian (see Table 1). The calculated PAs steadily increase in going from $1-\mathrm{BuOH}$ over $\mathrm{i}-\mathrm{BuOH}$ and $2-\mathrm{BuOH}$ to $\mathrm{t}-\mathrm{BuOH}$ indicating an increase in the strength of the $\mathrm{HB}$ between the BAS and the $\mathrm{BuOH}$ molecule, resulting in an enhancement of the partial proton transfer from the zeolite.

3.2.2. Physisorption Energy. The $\Delta E_{\mathrm{DFT}-\mathrm{D}}$ of the four butanols in H-ZSM-5 is similar at the straight channel but slightly different at the zigzag channel (Table 2).

At the straight channel, all butanols have virtually identical $\Delta E_{\mathrm{DFT}}$ and also indifferent $\Delta E_{\mathrm{D}}$. Assuming the similar steric constraints upon adsorption in H-ZSM-5 and in silicalite, the difference $\left(\delta\left[\Delta E_{\mathrm{DFT}}\right]\right)$ between $\Delta E_{\mathrm{DFT} / \mathrm{H}-\mathrm{ZSM}-\mathrm{5}}$ and $\Delta E_{\mathrm{DFT} /}$ silicalite can be used as a rough estimate of the $\mathrm{HB}$ strength for the physisorbed butanols. At the straight channel, the HB strength 
Table 5. Geometrical Parameters (pm $)^{a}$ and Formal Charges of Butanols Chemisorbed at the Straight and Zigzag Channels of H-ZSM-5 Obtained Using the pbc[DFT-D] Approach

\begin{tabular}{|c|c|c|c|c|c|c|c|c|}
\hline & & $\mathrm{H}_{\mathrm{z}}---\mathrm{O}_{\mathrm{a}}$ & $\mathrm{H}---\mathrm{O}_{\mathrm{b}}$ & $\mathrm{H}_{\mathrm{z}}-\mathrm{O}$ & $\mathrm{H}-\mathrm{O}$ & $q^{b}$ & $\mathrm{q}\left(\mathrm{O}_{\mathrm{a}}\right)^{b}$ & $\mathrm{q}\left(\mathrm{O}_{\mathrm{b}}\right)^{b}$ \\
\hline \multirow[t]{5}{*}{ straight channel } & 1-butoxonium & 153.2 & 146.7 & 105.0 & 106.9 & +0.77 & -1.56 & -1.55 \\
\hline & i-butoxonium & 155.6 & 147.6 & 104.2 & 106.6 & +0.78 & -1.55 & -1.55 \\
\hline & 2-butoxonium & 154.3 & 156.8 & 104.9 & 104.5 & +0.78 & -1.56 & -1.56 \\
\hline & t-butoxonium & 164.4 & 149.0 & 103.0 & 106.2 & +0.80 & -1.57 & -1.55 \\
\hline & t-butoxonium_sym ${ }^{c}$ & 152.5 & 157.8 & 105.1 & 104.0 & +0.81 & -1.57 & -1.55 \\
\hline \multirow[t]{5}{*}{ zigzag channel } & 1-butoxonium & 145.5 & 155.5 & 107.0 & 104.4 & +0.78 & -1.55 & -1.56 \\
\hline & 1-butoxonium_sym ${ }^{c}$ & 149.1 & 152.5 & 106.0 & 105.2 & +0.77 & -1.55 & -1.56 \\
\hline & i-butoxonium & 145.0 & 155.6 & 107.1 & 104.3 & +0.76 & -1.55 & -1.55 \\
\hline & 2-butoxonium & 153.0 & 153.7 & 104.6 & 104.8 & +0.78 & -1.55 & -1.57 \\
\hline & t-butoxonium & 155.0 & 149.7 & 104.2 & 105.4 & +0.76 & -1.55 & -1.55 \\
\hline
\end{tabular}

${ }^{a}$ Atom labels are defined in Figure $4 .{ }^{b} q, q\left(\mathrm{O}_{\mathrm{a}}\right)$, and $q\left(\mathrm{O}_{\mathrm{b}}\right)$ : formal charge of the protonated $\mathrm{C}_{4} \mathrm{H}_{9} \mathrm{OH}_{2}{ }^{+}$ion, $\mathrm{O}_{a}$, and $\mathrm{O}_{\mathrm{b}}$, respectively. ${ }^{c}$ Chemisorbed complexes with more symmetric $\mathrm{OH}$ covalent bond length.

Table 6. Geometrical Parameters (Distances in pm and Angles in Degree) ${ }^{a}$ of the Loaded H-ZSM-5 upon Chemisorption of Butanols at the Straight and Zigzag Channels Obtained Using the pbc[DFT-D] approach

\begin{tabular}{|c|c|c|c|c|c|c|c|c|}
\hline & & $\mathrm{Si}_{\mathrm{a}}-\mathrm{O}_{\mathrm{a}}$ & $\mathrm{Si}_{\mathrm{b}}-\mathrm{O}_{\mathrm{b}}$ & $\mathrm{Al}-\mathrm{O}_{\mathrm{a}}$ & $\mathrm{Al}-\mathrm{O}_{\mathrm{b}}$ & $\mathrm{O}_{\mathrm{a}} \mathrm{AlO}_{\mathrm{b}}$ & $\mathrm{Si}_{\mathrm{a}} \mathrm{O}_{\mathrm{a}} \mathrm{Al}$ & $\mathrm{Si}_{\mathrm{b}} \mathrm{O}_{\mathrm{b}} \mathrm{Al}$ \\
\hline Unloaded H-ZSM-5 & & 170.6 & 161.0 & 191.1 & 172.7 & 96.8 & 135.5 & 143.2 \\
\hline \multicolumn{9}{|c|}{ Chemisorbed } \\
\hline straight channel & 1-butoxonium & 162.4 & 163.6 & 178.9 & 180.5 & 98.8 & 138.4 & 138.4 \\
\hline \multirow{9}{*}{ zigzag channel } & i-butoxonium & 162.3 & 163.5 & 179.0 & 180.5 & 99.4 & 135.1 & 135.1 \\
\hline & 2-butoxonium & 162.4 & 162.8 & 179.3 & 179.4 & 99.7 & 139.5 & 139.5 \\
\hline & t-butoxonium & 162.1 & 163.1 & 178.3 & 180.1 & 100.8 & 136.6 & 136.6 \\
\hline & t-butoxonium_sym & 162.4 & 162.8 & 179.3 & 179.4 & 100.1 & 137.4 & 137.4 \\
\hline & 1-butoxonium & 162.7 & 162.9 & 180.1 & 179.6 & 98.6 & 136.0 & 136.0 \\
\hline & 1butoxonium_sym & 162.5 & 162.9 & 179.6 & 179.6 & 98.5 & 135.8 & 135.8 \\
\hline & i-butoxonium & 162.8 & 162.9 & 179.9 & 179.7 & 99.8 & 137.3 & 137.3 \\
\hline & 2-butoxonium & 162.4 & 162.8 & 179.3 & 179.9 & 99.3 & 135.4 & 135.4 \\
\hline & t-butoxonium & 162.6 & 162.8 & 179.8 & 180.2 & 100.1 & 135.6 & 135.6 \\
\hline
\end{tabular}

ranges from -73 to $-88 \mathrm{~kJ} \mathrm{~mol}^{-1}$ (see $\delta\left[\Delta E_{\mathrm{DFT}}\right]$, Table 2) in line with the increase in $\mathrm{PA}$ in going from $1-\mathrm{BuOH}$ to $\mathrm{t}-\mathrm{BuOH}$.

At the zigzag channel, a significantly larger $\Delta E_{\mathrm{DFT}}$ is calculated for $1-\mathrm{BuOH}$ in comparison with $2-\mathrm{BuOH}$ and $\mathrm{i}-\mathrm{BuOH}$. The $\mathrm{HB}$ strength for $2-\mathrm{BuOH}$ is however estimated to be somewhat larger as compared to $1-\mathrm{BuOH}$ and $\mathrm{i}-\mathrm{BuOH}$ (see $\delta\left[\Delta E_{\mathrm{DFT}}\right]$, Table 2) in agreement with the extent of partial proton transfer as mentioned above. Therefore, the less exothermic $\Delta E_{\mathrm{DFT}}$ of $2-\mathrm{BuOH}$ and $\mathrm{i}-\mathrm{BuOH}$ as compared with that of $1-\mathrm{BuOH}$ is ascribed to the pronounced increase in $E_{\text {strain }}$ of $+37 \mathrm{~kJ} \mathrm{~mol}^{-1}$ in going from $1-\mathrm{BuOH}$ to 2-BuOH. Also, the predominance of $\mathrm{E}_{\text {strain }}$ over $\mathrm{HB}$ and $\mathrm{vdW}$ interactions renders the $\Delta E_{\mathrm{DFT}-\mathrm{D}}$ of $\mathrm{i}-\mathrm{BuOH}$ and $2-\mathrm{BuOH}$ some $5-10 \mathrm{~kJ} \mathrm{~mol}^{-1}$ less exothermic than that of $1-\mathrm{BuOH}$ (Table 2).

The channel preference for the adsorption of butanols, as indicated by $\delta_{\mathrm{ch}}\left(\Delta E_{\text {DFT-D }}\right)$ in Table 3 , can be rationalized as a result of a subtle interplay between steric constraints and vdW interactions. Adsorption of $1-\mathrm{BuOH}$ and $2-\mathrm{BuOH}$ is energetically favorable at the compact zigzag channel while $\mathrm{i}-\mathrm{BuOH}$ is equally preferred at both channels. Note also that the physisorption of $\mathrm{t}-\mathrm{BuOH}$ is exclusive at the straight channel. Taking the most stable adsorbed complex of each $\mathrm{BuOH}$, the $\Delta E_{\mathrm{DFT}-\mathrm{D}}$ strength decreases in the order $1-\mathrm{BuOH}\left(-160 \mathrm{~kJ} \mathrm{~mol}^{-1}\right)>2-\mathrm{BuOH}(-155 \mathrm{~kJ}$ $\left.\mathrm{mol}^{-1}\right)>\mathrm{t}-\mathrm{BuOH}\left(-148 \mathrm{~kJ} \mathrm{~mol}^{-1}\right) \approx \mathrm{i}-\mathrm{BuOH}\left(-147 \mathrm{~kJ} \mathrm{~mol}^{-1}\right)$.

The $\mathrm{pbc}$ [DFT-D] calculations predict significantly different ranges of adsorption energy for H-ZSM-5 and silicalite ( -144 to $-160 \mathrm{vs}-51$ to $-79 \mathrm{~kJ} \mathrm{~mol}^{-1}$ ), which is in agreement with -113 to -161 versus -33 to $-83 \mathrm{vs} \mathrm{kJ} \mathrm{mol}^{-1}$ computed for the $\mathrm{C} 1-\mathrm{C} 4$ primary alcohols by Nguyen et $\mathrm{al}^{25}$ using the pbcDFT $+\mathrm{D}$ approach. In the calculations by Zamaraev et al., ${ }^{32}$ the magnitude of H-ZSM-5-alcohol and silicalite-alcohol interactions was however found to be largely identical ( -100 to -132 versus -109 to $-138 \mathrm{~kJ} \mathrm{~mol}^{-1}$, Table 2 ). While no experimental adsorption enthalpy for the butanols has been reported, a significant difference of $55-60 \mathrm{~kJ} \mathrm{~mol}^{-1}$ in favor of H-ZSM-5 against silicalite for the adsorption enthalpy of methanol, ethanol, and 1-propanol is observed in the experimental study reported by Lee et al. ${ }^{26}$ The results reported by Zamaraev et al. ${ }^{32}$ seem to indicate that the energy minimization procedure supplemented by a MC/MD algorithm is less suited for the description of the alcohol-zeolite interactions.

3.3. Chemisorption. 3.3.1. Geometry. All chemisorbed complexes are characterized by two largely indifferent $\mathrm{HBs}$ and two almost equivalent covalent $\mathrm{OH}$ bonds (Table 5). Moreover, the 
Table 7. Chemisorption Energies $\left(\Delta E_{\mathrm{chem}} \mathrm{kJ} \mathrm{mol}^{-1}\right)$, DFT-D Proton Transfer Energies $\left(\Delta E_{\mathrm{pt}}, \mathrm{kJ} \mathrm{mol}^{-1}\right)$ and Iron Pair Interaction Energies (IP, $\mathrm{kJ} \mathrm{mol}^{-1}$ ) of Butanols in H-ZSM-5 Obtained Using the pbc[DFT-D] Approach $\left(\mathrm{IP}_{\mathrm{DFT}-\mathrm{D}}=\Delta E_{\mathrm{DFT}-\mathrm{D}}-\mathrm{DP}^{\mathrm{a}}-\mathrm{PA}_{\text {, }}\right.$ $\mathrm{IP}_{\mathrm{DFT}}=\Delta E_{\mathrm{DFT}}-\mathrm{DP}^{a}-\mathrm{PA}$, and $\left.\mathrm{IP}_{\mathrm{D}}=\mathrm{IP}_{\mathrm{DFT}-\mathrm{D}}-\mathrm{IP}_{\mathrm{DFT}}\right)$

\begin{tabular}{|c|c|c|c|c|c|c|c|c|}
\hline & & \multicolumn{3}{|c|}{$\Delta E_{\text {chem }}$} & \multirow[b]{2}{*}{$\Delta E_{\mathrm{pt}, \mathrm{DFT}-\mathrm{D}}$} & \multicolumn{3}{|c|}{ IP } \\
\hline & & $\Delta E_{\mathrm{DFT}-\mathrm{D}}$ & $\Delta E_{\mathrm{DFT}}$ & $\Delta E_{\mathrm{D}}$ & & $\mathrm{IP}_{\mathrm{DFT}-\mathrm{D}}$ & $\mathrm{IP}_{\mathrm{DFT}}$ & $\mathrm{IP}_{\mathrm{D}}$ \\
\hline \multirow[t]{5}{*}{ straight channel } & 1-butoxonium & -150 & -84 & -66 & -2 & -552 & -486 & -66 \\
\hline & i-butoxonium & -147 & -88 & -59 & 0 & -547 & -488 & -59 \\
\hline & 2-butoxonium & -146 & -88 & -58 & -1 & -533 & -475 & -58 \\
\hline & t-butoxonium & -150 & -86 & -64 & -2 & -526 & -462 & -64 \\
\hline & t-butoxonium_sym & -151 & -88 & -63 & -3 & -527 & -464 & -63 \\
\hline \multirow[t]{5}{*}{ zigzag channel } & 1-butoxonium & -164 & -79 & -85 & -4 & -566 & -481 & -85 \\
\hline & 1-butoxonium_sym & -163 & -81 & -82 & -3 & -565 & -483 & -82 \\
\hline & i-butoxonium & -146 & -51 & -95 & +1 & -546 & -451 & -95 \\
\hline & 2-butoxonium & -157 & -61 & -96 & -2 & -544 & -448 & -96 \\
\hline & t-butoxonium & -148 & -45 & -103 & & -524 & -421 & -103 \\
\hline
\end{tabular}

${ }^{a}$ DP: Calculated deprotonation energy $\left(1236 \mathrm{~kJ} \mathrm{~mol}^{-1}\right)$ of the acid site Al12-O24(H)Si12 of H-ZSM-5 taken from ref 56.

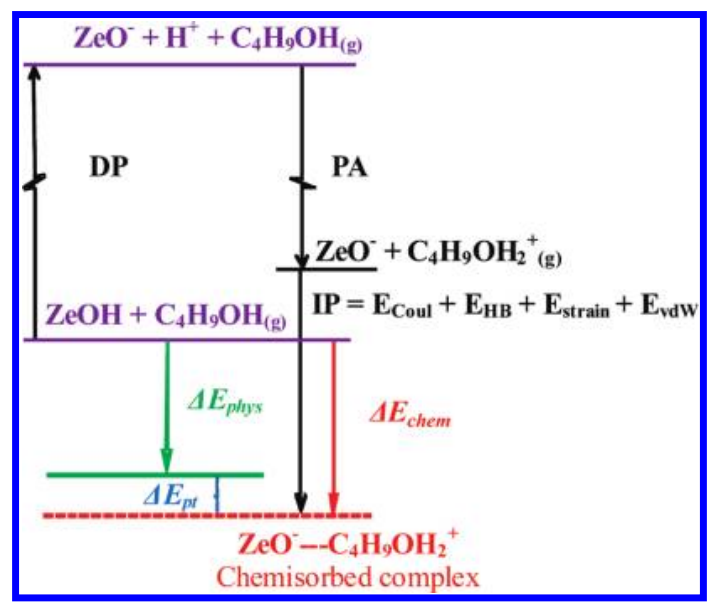

Figure 5. Energy levels corresponding to different interactions between the gas-phase butanol and zeolite.

Bader analysis allocated a total charge of +0.76 to +0.81 to the butoxonium fragments, which is in agreement with the range of +0.75 to +0.78 computed for oxonium species of $\mathrm{C} 1-\mathrm{C} 3$ primary alcohols. ${ }^{18,25}$ Formal charges located on the $\mathrm{O}_{\mathrm{a}}$ and $\mathrm{O}_{\mathrm{b}}$ are identical for all butoxonium ions (Table 5), indicating that the charge allocation pattern is similar for all chemisorbed complexes. As a consequence of the complete proton transfer from the BAS to the butanol molecule, the zeolite framework is distorted to a greater extent as compared with that observed upon physisorption (Table 6).

3.3.2. Chemisorption Energy. The chemisorption energies of the butanols are shown in Table 7. At the straight channel, all butanols have comparable $\Delta E_{\mathrm{DFT}-\mathrm{D}}$ and largely similar $\Delta E_{\mathrm{DFT}}$ and $\Delta E_{\mathrm{D}}$. At the zigzag channel, the $\Delta E_{\mathrm{DFT}-\mathrm{D}}$ strength decreases in going from $1-\mathrm{BuOH}$ over $2-\mathrm{BuOH}$ to $\mathrm{i}-\mathrm{BuOH}$ and $\mathrm{t}-\mathrm{BuOH}$ and broader ranges of $\Delta E_{\mathrm{DFT}}$ and $\Delta E_{\mathrm{D}}$ are observed.

Despite the difference in $\mathrm{O}-\mathrm{H}$ bond length, significantly similar chemisorption energies are computed for t-butoxonium and t-butoxonium_sym at the straight channel as well as for 1-butoxonium and 1-butoxonium_sym at the zigzag channel (Table 7), revealing the very flat potential energy surfaces (PES) for the fluctuation of the $\mathrm{O}-\mathrm{H}$ bonds of the oxonium ions. ${ }^{18,25}$
Assuming that the ion pair interactions (IPs) between the negatively charged zeolite and the protonated butoxonium ions mainly consist of stabilizing $\mathrm{HB}\left(E_{\mathrm{HB}}\right)$, Coulomb $\left(E_{\mathrm{Coul}}\right)$, and vdW $\left(E_{\mathrm{vdW}}\right)$ interactions and destabilizing steric constraints $\left(E_{\text {strain }}\right)$, an estimate of the stabilization of the gas phase butoxonium ions by the negatively charged zeolite $\left(\mathrm{ZeO}^{-}-\mathrm{-}_{4} \mathrm{H}_{9} \mathrm{OH}_{2}{ }^{+}\right)$can be obtained based on the thermodynamic cycle presented in Figure 5. In this study, the same BAS site of H-ZSM-5 has been considered for all adsorption complexes and the deprotonation energy of $1236 \mathrm{~kJ}$ $\mathrm{mol}^{-1}$ as reported by Brand et al. ${ }^{56}$ was used to calculate the IPs

$$
\begin{gathered}
\mathrm{IP}_{\mathrm{DFT}-\mathrm{D}}=\Delta E_{\mathrm{DFT}-\mathrm{D}}-\mathrm{DP}-\mathrm{PA} \\
=E_{\mathrm{Coul}}+E_{\mathrm{HB}}+E_{\mathrm{vdW}}+E_{\text {strain }} \\
\mathrm{IP}_{\mathrm{DFT}}=\Delta E_{\mathrm{DFT}}-\mathrm{DP}-\mathrm{PA}=E_{\mathrm{Coul}}+E_{\mathrm{HB}}+E_{\text {strain }} \\
\mathrm{IP}_{\mathrm{D}}=\mathrm{IP}_{\mathrm{DFT}-\mathrm{D}}-\mathrm{IP}_{\mathrm{DFT}}=\Delta E_{\mathrm{D}}=E_{\mathrm{vdW}}
\end{gathered}
$$

At the straight channel, the total $\mathrm{IP}_{\mathrm{DFT}-\mathrm{D}}$ strength decreases in the following order: $1-\mathrm{BuOH}>\mathrm{i}-\mathrm{BuOH}>2-\mathrm{BuOH}>\mathrm{t}-\mathrm{BuOH}$ (Table 7) with increasing bulkiness of the butyl chain. For all butanols, the stabilizing vdW contribution, $\mathrm{IP}_{\mathrm{D}}$, is roughly the same and amounts to some $-60 \mathrm{~kJ} \mathrm{~mol}^{-1}$. In contrast, the DFT contribution, $\mathrm{IP}_{\mathrm{DFT}}$, decreases by $22-24 \mathrm{~kJ} \mathrm{~mol}^{-1}$ in going from $1-\mathrm{BuOH}$ to $\mathrm{t}-\mathrm{BuOH}$, which can be mainly ascribed to the aforementioned increase in $E_{\text {strain }}$ of $15 \mathrm{~kJ} \mathrm{~mol}^{-1}$ (Table 2) since all the butoxonium ions have rather similar structural parameters as well as formal charges and can thus be expected to have rather similar $E_{\mathrm{HB}}$ as well as $E_{\text {Coul }}$ contributions.

At the zigzag channel, the decrease of $60 \mathrm{~kJ} \mathrm{~mol}^{-1}$ in $\mathrm{IP}_{\mathrm{DFT}}$ in going from $1-\mathrm{BuOH}$ to $\mathrm{t}-\mathrm{BuOH}$ can be mainly ascribed to the increase in $E_{\text {strain }}$ of $63 \mathrm{~kJ} \mathrm{~mol}^{-1}$ (see Table 2). Despite the increase in $\mathrm{IP}_{\mathrm{D}}$ from -85 to $-103 \mathrm{~kJ} \mathrm{~mol}^{-1}$, the $\mathrm{IP}_{\mathrm{DFT}-\mathrm{D}}$ follows the similar trend as the IP $\mathrm{DFT}_{\mathrm{DF}}$.

The differences in $\mathrm{IP}_{\mathrm{DFT}}$ and $\mathrm{IP}_{\mathrm{D}}$ contributions can also be used to rationalize the influence of the pore dimensions on the stability of the chemisorbed butoxoniums. Clearly, the interplay between steric constrains and vdW interactions accounts for the stronger chemisorption of $1-\mathrm{BuOH}$ and $2-\mathrm{BuOH}$ at the zigzag channel. The chemisorption of $\mathrm{i}-\mathrm{BuOH}$ and $\mathrm{t}-\mathrm{BuOH}$ is however 
equally preferred by the straight and zigzag channels (see $\delta_{\mathrm{ch}^{-}}$ $\left[\mathrm{IP}_{\mathrm{DFT}}\right]$ and $\delta_{\mathrm{ch}}\left[\mathrm{IP}_{\mathrm{D}}\right]$, Table 8$)$.

3.3.3. Proton Transfer Energy. The very small proton transfer energies observed at the straight $\left(0\right.$ to $\left.-3 \mathrm{~kJ} \mathrm{~mol}^{-1}\right)$ as well as at the zigzag $\left(+1\right.$ to $\left.-4 \mathrm{~kJ} \mathrm{~mol}^{-1}\right)$ channel are indicative of the very flat potential energy surfaces for the proton transfer from the zeolite to the alcohols (see $\Delta E_{\mathrm{pt}}$, Table 7). Previous pbcDFT calculations also predicted very small energy differences between the protonated and hydrogen bonded complexes for a range of $\mathrm{C} 1-\mathrm{C} 4$ primary alcohols. ${ }^{18,21,25}$ For the adsorption of methanol in zeolite, cluster calculations at the HF-SCF, MP2, and DFT levels of theory computed a broad and shallow potential energy surface that accommodates two equivalent neutral complexes with the ion-pair transition state connecting them. ${ }^{15,16}$ It is apparent from the present periodic calculations that the physisorbed and chemisorbed complexes are the most stable species on the PES for the adsorption of butanols in H-ZSM-5 at $0 \mathrm{~K}$ The assumption of an equilibrium between these stable complexes is corroborated by the very small difference in energy between the physisorbed and chemisorbed complexes.

3.4. Stability of Adsorbed Complexes. Figure 6 represents the thermodynamic cycle for the formation of both physisorbed and chemisorbed complexes from the unloaded zeolite and the elements taken as the reference state, allowing a direct comparison of the stability of the adsorbed complexes of the different alcohols. The stabilization energy of the adsorbed complexes ( $\Delta E_{\text {physstab }}$ or $\Delta E_{\text {chemstab }}$ ) relative to the elements dependents on the standard enthalpy of formation, $\Delta H_{\mathrm{f}}^{0}$, of the gas-phase alcohol $^{57}$ and the adsorption energy $\left(\Delta E_{\mathrm{phys}}\right.$ or $\left.\Delta E_{\mathrm{chem}}\right)$ of the alcohol in H-ZSM-5

$$
\begin{gathered}
\Delta E_{\text {phys, stab }}=\Delta E_{\text {phys }}+\Delta H_{\mathrm{f}}^{0} \\
\Delta E_{\text {chem, stab }}=\Delta E_{\text {chem }}+\Delta H_{\mathrm{f}}^{0}
\end{gathered}
$$

Table 8. Difference $\left(\delta_{\mathrm{ch}}\left[\Delta E_{\mathrm{DFT}-\mathrm{D}}\right], \mathrm{kJ} \mathrm{mol}^{-1}=\Delta E_{\text {DFT-D }}{ }^{\text {zigzag }}\right.$ $\left.-\Delta E_{\mathrm{DFT}-\mathrm{D}}^{\text {straight }}\right)$ in $\Delta E_{\mathrm{chem}}$ and Difference $\left(\delta_{\mathrm{ch}}, \mathrm{kJ} \mathrm{mol}^{-1}=\right.$ IP $^{\text {zigzag }}-$ IP $\left.^{\text {straight }}\right)$ in IP Energies Computed between the Zigzag and Straight Channel of H-ZSM-5 Obtained Using the

\begin{tabular}{|c|c|c|c|c|}
\hline & $\Delta E_{\text {chem }}$ & \multicolumn{3}{|c|}{ IP } \\
\hline & $\delta_{\mathrm{ch}}\left[\Delta E_{\text {DFT-D }}\right]$ & $\delta_{\mathrm{ch}}\left[\mathrm{IP}_{\mathrm{DFT}-\mathrm{D}}\right]$ & $\delta_{\mathrm{ch}}\left[\mathrm{IP}_{\mathrm{DFT}}\right]$ & $\delta_{\text {ch }}\left[\operatorname{IP}_{D}\right]$ \\
\hline $1-\mathrm{BuOH}$ & -14 & -14 & +5 & -19 \\
\hline $\mathrm{i}-\mathrm{BuOH}$ & +1 & +1 & +37 & -36 \\
\hline 2-BuOH & -11 & -11 & +27 & -38 \\
\hline $\mathrm{t}-\mathrm{BuOH}$ & +2 & +2 & +41 & -39 \\
\hline
\end{tabular}
pbc[DFT-D] Approach
Table 9 presents the stabilization energy of all adsorbed complexes in H-ZSM-5. At the straight channel, the stability of both physisorbed and chemisorbed complexes increases in going from $1-\mathrm{BuOH}$ over $\mathrm{i}-\mathrm{BuOH}$ and $2-\mathrm{BuOH}$ to $\mathrm{t}-\mathrm{BuOH}$. The largest difference in stability is observed between the $1-\mathrm{BuOH}$ and $\mathrm{t}-\mathrm{BuOH}$ chemisorbed complexes, amounting to $38 \mathrm{~kJ} \mathrm{~mol}^{-1}$ in favor of $\mathrm{t}-\mathrm{BuOH}$. At the zigzag channel, the stability of the adsorbed complexes increases in the following order: $\mathrm{i}-\mathrm{BuOH}<$ $1-\mathrm{BuOH}<2-\mathrm{BuOH}<\mathrm{t}-\mathrm{BuOH}$.

3.5. Partial Hessian Vibrational Analysis. Three different interpretations ${ }^{17}$ have been proposed to explain the experimentally observed triplet of bands at approximately 2800-3000, $2400-2600$, and $1500-1700 \mathrm{~cm}^{-1}$ of alcohols adsorbed in several zeolites. ${ }^{6-11}$ The first one assumes the formation of protonated alcohol $\left(\mathrm{ROH}_{2}{ }^{+}\right)$and assigns the three bands to the symmetric $\left(v_{\mathrm{s}}\right)$ and asymmetric $\left(v_{\mathrm{a}}\right) \mathrm{HOH}$ stretch and $(\delta) \mathrm{HOH}$ bending, respectively. ${ }^{9,10}$ The second interpretation for the triplet is based on a Fermi resonance of the very broad $v(\mathrm{OH})$ stretch with the overtones of the in-plane $\delta_{\mathrm{i}}(\mathrm{OH})$ and out-ofplane $\delta_{\mathrm{o}}(\mathrm{OH})$ bending of zeolite in physisorbed complexes ( $\mathrm{Ze}-\mathrm{OH}--\mathrm{Y})$ such as the methanol-zeolite. ${ }^{8}$ The last interpretation proposes an equilibrium between chemisorbed and physisorbed complexes ( $\left.\mathrm{Ze}-\mathrm{OH}--\mathrm{Y} \leftrightarrow \mathrm{Ze}-\mathrm{O}^{-}--\mathrm{YH}^{+}\right){ }^{11}$ Given the very flat PES for the proton transfer, vibrations of the $\mathrm{H}_{\mathrm{z}}$ proton in both the physisorbed and chemisorbed complexes are therefore to some extent characterized by anharmonicity. ${ }^{18,20}$. Previous calculations ${ }^{18,58,59}$ indicated that anharmonicity reduces the $\mathrm{O}_{\mathrm{a}} \mathrm{H}_{\mathrm{z}}$ stretch of unloaded and loaded zeolites by $150-200 \mathrm{~cm}^{-1}$. In the present work, vibrations of adsorbed complexes were analyzed within the harmonic approximation only since computation of anharmonic frequencies is not currently available within the VASP code. Harmonic frequencies

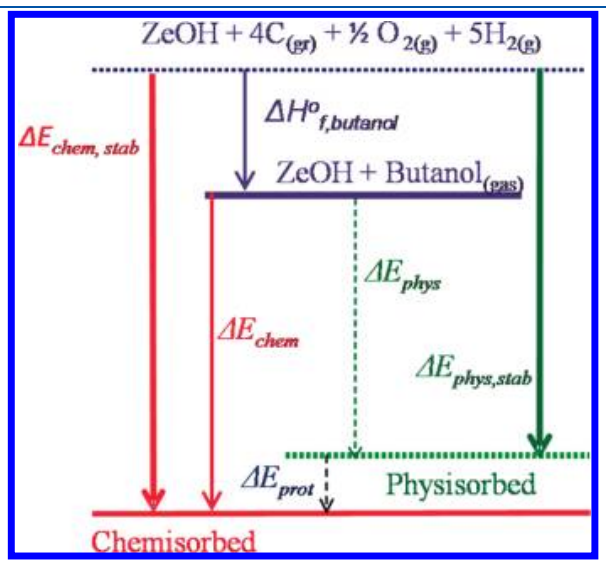

Figure 6. Stability of physisorbed and chemisorbed complexes relative to the elements.

\begin{tabular}{|c|c|c|c|c|c|}
\hline & \multicolumn{2}{|c|}{ straight channel } & \multicolumn{2}{|c|}{ zigzag channel } & \multirow[b]{2}{*}{$\Delta H_{\mathrm{f}}^{0 a}$} \\
\hline & $\Delta E_{\text {phys }}+\Delta H_{\mathrm{f}}^{0}$ & $\Delta E_{\text {chem }}+\Delta H_{\mathrm{f}}^{0}$ & $\Delta E_{\text {phys }}+\Delta H_{\mathrm{f}}$ & $\Delta E_{\text {chem }}+\Delta H_{\mathrm{f}}^{0}$ & \\
\hline 1-BuOH & -423 & -425 & -435 & -439 & -275 \\
\hline $\mathrm{i}-\mathrm{BuOH}$ & -431 & -431 & -431 & -430 & -284 \\
\hline 2-BuOH & -437 & -438 & -448 & -450 & -293 \\
\hline $\mathrm{t}-\mathrm{BuOH}$ & -460 & -463 & & -460 & -312 \\
\hline
\end{tabular}

Table 9. Stability of Physisorbed and Chemisorbed BuOH-H-ZSM-5 Complexes Relative to the Elements

${ }^{a}$ Standard formation enthalpies $\left(\mathrm{kJ} \mathrm{mol}^{-1}\right)$ of the gas-phase alcohols taken from ref 57. 
Table 10. Selected Harmonic Vibrational Frequencies $\left(\mathrm{cm}^{-1}\right)^{a}$ for Unloaded H-ZSM-5, Gas-Phase Butanols, and the Most Stable Physisorbed Complexes of Butanols in H-ZSM-5 Obtained Using the pbc[DFT-D] Approach ${ }^{b}$

\begin{tabular}{|c|c|c|c|c|c|c|c|}
\hline & $v(\mathrm{CH})$ & $\delta(\mathrm{CH})$ & $\delta\left(\mathrm{CH}_{3}\right)$ & $v(\mathrm{OH})$ & $v\left(\mathrm{O}_{\mathrm{a}} \mathrm{H}_{\mathrm{z}}\right)^{c}$ & $\delta_{\mathrm{i}}\left(\mathrm{O}_{\mathrm{a}} \mathrm{H}_{2}\right)^{c}$ & $\delta_{\mathrm{o}}\left(\mathrm{O}_{\mathrm{a}} \mathrm{H}_{\mathrm{z}}\right)$ \\
\hline H-ZSM-5 & & & & & 3737 & 1110 & 353 \\
\hline \multicolumn{8}{|l|}{ 1-BuOH } \\
\hline gas phase & $2896-3035$ & $1427-1464$ & 1351 & 3759 & & & \\
\hline $\begin{array}{c}2 \mathrm{HB}_{-} \text {zig__ } \mathrm{O}_{\mathrm{a}} \mathrm{H}_{2} \\
\mathrm{i}-\mathrm{BuOH}\end{array}$ & $2964-3067$ & $1427-1460$ & 1350 & 3425 & 1392 & 1669 & 1171 \\
\hline gas phase & $2892-3056$ & $1423-1454$ & 1349 & 3757 & & & \\
\hline $\begin{array}{c}\text { 2HB_str_ } \mathrm{O}_{\mathrm{a}} \mathrm{H}_{z} \\
\text { 2-BuOH }\end{array}$ & $2945-3057$ & $1426-1458$ & 1366 & 3497 & 1403 & 1647 & 1187 \\
\hline gas phase & $2882-3046$ & $1408-1445$ & 1348 & 3743 & & & \\
\hline $\begin{array}{c}2 \mathrm{HB}_{z} \mathrm{zig}{ }_{-} \mathrm{O}_{\mathrm{a}} \mathrm{H}_{z} \\
\mathrm{t}-\mathrm{BuOH}\end{array}$ & $2956-3108$ & $1415-1454$ & 1374 & 3427 & 1370 & 1717 & 1203 \\
\hline gas phase & $2942-3053$ & $1405-1450$ & 1355 & 3696 & & & \\
\hline 2HB_str_- $\mathrm{O}_{\mathrm{a}} \mathrm{H}_{2}$ & $2961-3077$ & $1414-1455$ & 1375 & 3368 & 1478 & 1757 & 1203 \\
\hline
\end{tabular}

Table 11. Selected Harmonic Vibration Frequencies $\left(\mathrm{cm}^{-1}\right)^{a}$ for the Most Stable Chemisorbed Complexes of Butanols in H-ZSM5 Obtained Using the pbc[DFT-D] Approach ${ }^{b}$

\begin{tabular}{|c|c|c|c|c|c|c|}
\hline & $v(\mathrm{CH})$ & $\delta(\mathrm{CH})$ & $\delta\left(\mathrm{CH}_{3}\right)$ & $v_{\mathrm{s}}\left(\mathrm{HOH}_{\mathrm{z}}\right)$ & $v_{\mathrm{a}}\left(\mathrm{HOH}_{\mathrm{z}}\right)$ & $\delta\left(\mathrm{HOH}_{\mathrm{z}}\right)$ \\
\hline 1-butoxonium_zig & $2965-3082$ & $1423-1452$ & 1357 & 2669 & 2243 & 1642 \\
\hline 1-butoxonium_zig_sym & $2967-3080$ & $1423-1452$ & 1356 & 2603 & 2319 & 1643 \\
\hline i-butoxonium_str & $2947-3060$ & $1419-1447$ & 1373 & 2666 & 2292 & 1628 \\
\hline 2-butoxonium_zig & $2985-3086$ & $1420-1444$ & 1358 & 2671 & 2459 & 1634 \\
\hline t-butoxonium_str & $2966-3068$ & $1413-1456$ & 1377 & 2812 & 2325 & 1626 \\
\hline t-butoxonium_str_sym & $2964-3068$ & $1413-1457$ & 1375 & 2711 & 2434 & 1635 \\
\hline
\end{tabular}

reported here provide a qualitative agreement with the experimental IR data.

Selected harmonic frequencies of the most stable physisorbed and chemisorbed complexes, that is, 2HB_zig_O $\mathrm{O}_{\mathrm{a}} \mathrm{H}_{\mathrm{z}}$ and butoxonium_zig of $1-\mathrm{BuOH}$ and $2-\mathrm{BuOH}$ together with $2 \mathrm{HB}$ sstr $\mathrm{O}_{\mathrm{a}} \mathrm{H}_{\mathrm{z}}$ and butoxonium str of $\mathrm{i}-\mathrm{BuOH}$ and $\mathrm{t}-\mathrm{BuOH}$ are presented in Tables 10 and 11. For a complete discussion on harmonic vibrations of butanol isomers adsorbed in H-ZSM-5, see the Supporting Information (S7). Assuming an equilibrium between the physisorbed and chemisorbed complexes, the three much debated IR regions of the four butanols ${ }^{27-31}$ can be explained. The first region, $2800-3000 \mathrm{~cm}^{-1}$, corresponds solely to the $v(\mathrm{CH})$ stretching $\left(2945-3108 \mathrm{~cm}^{-1}\right.$, Tables 10 and 11) of both physisorbed and chemisorbed complexes. The broad bands in the second region $2000-2700 \mathrm{~cm}^{-1}$, can be assigned to the symmetric $v_{\mathrm{s}}\left(\mathrm{HOH}_{\mathrm{z}}\right)$ and asymmetric $v_{\mathrm{a}}\left(\mathrm{HOH}_{\mathrm{z}}\right)$ stretching modes of the chemisorbed complexes. The third region, centered around $1500-1600 \mathrm{~cm}^{-1}$, may be attributed to the chemisorbed $\delta\left(\mathrm{HOH}_{\mathrm{z}}\right)$ and physisorbed in plane $\delta_{\mathrm{i}}\left(\mathrm{O}_{\mathrm{a}} \mathrm{H}_{\mathrm{z}}\right)$ bending modes. The observed IR regions ${ }^{27-31}$ for $\delta\left(\mathrm{CH}_{3}\right)$ at $1380-1391 \mathrm{~cm}^{-1}$ and $\delta(\mathrm{CH})$ at $1446-1470 \mathrm{~cm}^{-1}$ find a good agreement with the calculated values $\left(1380-1391\right.$ and $1446-1470 \mathrm{~cm}^{-1}$ for respective $\delta\left(\mathrm{CH}_{3}\right)$ and $\delta(\mathrm{CH})$, Tables 10 and 11). The highest frequency band around $3500-3700 \mathrm{~cm}^{-1}$ observed for i-BuOH and $\mathrm{t}-\mathrm{BuOH}$ in $\mathrm{H}-\mathrm{ZSM}-5^{30,31}$ can be assigned to the $v(\mathrm{OH})$ of the
2-HB physisorbed complexes $\left(3368-3497 \mathrm{~cm}^{-1}\right)$ and/or to the $v\left(\mathrm{O}_{\mathrm{a}} \mathrm{H}_{\mathrm{z}}\right)$ of free BAS $\left(3737 \mathrm{~cm}^{-1}\right)$.

\section{CONCLUSIONS}

The results reported here demonstrate that the pbc[DFT-D] approach is an efficient method for obtaining detailed information on the structure and energy of alcohols adsorbed in H-ZSM5 zeolite, taking into account both bonded and nonbonded interactions. Having dimensions comparable to the channel's diameter of H-ZSM-5, the four butanols prove to be very useful probe molecules to evaluate the influence of the pore structure and size effects of the H-ZSM-5 framework.

The effect of the zeolite framework on the physisorption of the isomeric butanols results from an interplay of steric constraints, vdW dispersive interactions and hydrogen bonding between the $\mathrm{BAS}$ and the alcohol. In essence, steric constraints destabilize the alcohol-zeolite interaction and have a pronounced influence at the more confined zigzag channel, especially for the branched alcohols. In contrast, the dispersive vdW interactions contribute to the stabilization of the butanols inside the zeolite pores and fully counterbalance or even overweighs the steric constraints. The strength of the hydrogen bonding increases with increasing $\mathrm{PA}$ of the alcohol. Consequently, the physisorption of $\mathrm{i}-\mathrm{BuOH}$ and $\mathrm{t}-\mathrm{BuOH}$ is equally preferred by the zigzag and straight 
channels while $1-\mathrm{BuOH}$ and $2-\mathrm{BuOH}$ favorably physisorb at the zigzag channel. For chemisorptions, the same preference as for physisorption results from an interplay between the steric constrains and dispersive vdW interactions since Coulomb and hydrogen bonding interactions are similar for the four isomeric butoxonium ions.

The concept of an equilibrium between the physisorbed and chemisorbed minima is corroborated by a very delicate difference in energy between them. It explains the experimental IR spectra of the four butanols adsorbed in H-ZSM-5.

\section{ASSOCIATED CONTENT}

S Supporting Information. Geometrical illustrations of butanols adsorbed in silicalite and H-ZSM-5 are given. Performance of pbcDFT $+\mathrm{D}$ versus pbc[DFT-D] with respect to geometries, adsorption energies, and vibrational frequencies of adsorbed complexes is detailed. Also, geometrical parameters and adsorption energies of butanols physisorbed over the BAS $\mathrm{O}_{\mathrm{a}} \mathrm{Al}\left[\mathrm{O}_{\mathrm{b}} \mathrm{H}_{\mathrm{z}}\right]$ are presented. This material is available free of charge via the Internet at http://pubs.acs.org.

\section{AUTHOR INFORMATION}

\section{Corresponding Author}

*Tel: +32 (0)9 264 4516. Fax: +32 (0)9 264 4999. E-mail: MarieFrancoise.Reyniers@ugent.be.

\section{ACKNOWLEDGMENT}

This work is supported by the Long Term Structural Methusalem Funding by the Flemish Government, Grant BOF09/ 01M00409, the FWO (Fund for Scientific Research Flanders), the BELSPO (Belgian Federal Science Policy Office), and by the E.C. (Network of Excellence IDECAT, NMP3-CT-2005011730). All PHVA calculations for periodic systems were carried out using the Stevin Supercomputer Infrastructure at Ghent University.

\section{REFERENCES}

(1) Smith, J. V. Chem. Rev. 1988, 88, 149-182.

(2) Smit, B.; Maesen, T. L. M. Chem. Rev. 2008, 108, 4125-4184.

(3) Corma, A.; Iborra, S.; Velty, A. Chem. Rev. 2007, 107, 2411-2502.

(4) Huber, G. W.; Corma, A. Angew. Chem., Int. Ed. 2007, 46, 7184-7201.

(5) Huber, G. W.; Iborra, S.; Corma, A. Chem. Rev. 2006, 106, 4044-4098.

(6) Aronson, M. T.; Gorte, R. J.; Farneth, W. E. J. Catal. 1987, 105, $455-468$.

(7) Aronson, M. T.; Gorte, R. J.; Farneth, W. E. J. Catal. 1986, 98, 434-443.

(8) Kotrla, J.; Nachtigallová, D.; Kubelková, L.; Heeribout, L.; Doremieux-Morin, C.; Fraissard, J. J. Phys. Chem. B 1998, 102, 2454-2463.

(9) Izmailova, S. G.; Karetina, I. V.; Khvoshchev, S.; Shubaeva, M. A. J. Colloid Interface Sci. 1994, 165, 318-324.

(10) Mirth, G.; Lercher, J. A.; Anderson, M. W.; Kinowski, J. J. Chem. Soc., Faraday Trans. 1990, 86, 3039-3044.

(11) Kubelková, L.; Nováková, J.; Nedomová, K. J. Catal. 1990, 124, 441-450.

(12) van Santen, R. A. Catal. Today 1997, 38, 377-390.

(13) van Santen, R. A.; Kramer, G. J. Chem. Rev. 1995, 95, 637-660.

(14) Sauer, J.; Ugliengo, P.; Garrone, E.; Saunders, V. R. Chem. Rev. 1994, 94, 2095-2160.

(15) Haase, F.; Sauer, J. J. Am. Chem. Soc. 1995, 117, 3780-3789.
(16) Blaszkowski, S. R.; van Santen, R. A. J. Phys. Chem. 1995, 99, 11728-11738.

(17) Pelmenschikov, A. G.; van Wolput, J. H. M. C.; Jänchen, J.; van Santen, R. A. J. Phys. Chem. 1995, 99, 3612-3617.

(18) Shah, R.; Gale, J. D.; Payne, M. C. J. Phys. Chem. 1996, 100, 11688-11697.

(19) Haase, F.; Sauer, J.; Hutter, J. Chem. Phys. Lett. 1997, 266, 397-402.

(20) Stich, I.; Gale, J. D.; Terakura, K.; Payne, M. C. Chem. Phys. Lett. 1998, 283, 402-408.

(21) Haase, F.; Sauer, J. Microporous Mesoporous Mater. 2000, 35-36, 379-385.

(22) Svelle, S.; Tuma, C.; Rozanska, X.; Kerber, T.; Sauer, J. J. Am. Chem. Soc. 2009, 131, 816-825.

(23) Derouane, E. G. J. Mol. Catal. A: Chem. 1998, 134, 29-45.

(24) Stich, I.; Gale, J. D.; Terakura, K.; Payne, M. C. J.Am. Chem. Soc. 1999, 121, 3292-3302.

(25) Nguyen, C. M.; Reyniers, M. F.; Marin, G. B. Phys. Chem. Chem. Phys. 2010, 12, 9481-9493.

(26) Lee, C. C.; Gorte, R. J.; Farneth, W. E. J. Phys. Chem. B 1997, $101,3811-3817$.

(27) Makarova, M. A.; Paukshtis, E. A.; Thomas, J. M.; Williams, C.; Zamaraev, K. I. J. Catal. 1994, 149, 36-51.

(28) Makarova, M. A.; Williams, C.; Zamaraev, K. I. J. Chem. Soc., Faraday Trans. 1994, 90, 2147-2153.

(29) Makarova, M. A.; Williams, C.; Romannikov, V. N.; Zamaraev, K. I. J. Chem. Soc., Faraday Trans. 1990, 86, 581-584.

(30) Williams, C.; Makarova, M. A.; Malysheva, L. V.; Paukshtis, E. A.; Zamaraev, K. I. J. Chem. Soc., Faraday Trans. 1990, 86, 3473-3485.

(31) Williams, C.; Makarova, M. A.; Malysheva, L. V.; Paukshtis, E. A.; Talsi, E. P.; Thomas, J. M.; Zamaraev, K. I. J. Catal. 1991, 127, 377-392.

(32) Shubin, A. A.; Catlow, C. R. A.; Thomas, J. M.; Zamaraev, K. I. Proc.-R. Soc., Sect. A: Math. Phys. Sci. 1994, 446, 411-427.

(33) Kerber, T.; Sierka, M.; Sauer, J. J. Comput. Chem. 2008, 29, 2088-2097.

(34) Grimme, S. J. Comput. Chem. 2006, 27, 1787-1799.

(35) Sklenak, S.; Dedecek, J.; Li, C.; Wichterlova, B.; Gabova, V.; Sierka, M.; Sauer, J. Phys. Chem. Chem. Phys. 2009, 11, 1237-1247.

(36) Gabova, V.; Dedecek, J.; Cejka, J. Chem. Commun. 2003, 10, 1196-1197.

(37) Schroder, K. P.; Sauer, J.; Leslie, M.; Richard, C.; Catlow, C. R. A. Zeolites 1992, 12, 20-23.

(38) Nachtigallova, D.; Nachtigall, P.; Sierka, M.; Sauer, J. Phys. Chem. Chem. Phys. 1999, 1, 2019-2026.

(39) Sazama, P.; Dedecek, J.; Gabova, V.; Wichterlova, B.; Spoto, G.; Bordiga, S. J. Catal. 2008, 254, 180-189.

(40) Alvarado-Swaisgood, A. E.; Barr, M. K.; Hay, P. J.; Redondo, A. J. Phys. Chem. 1991, 95, 10031-10036.

(41) Brändle, M.; Sauer, J. J. Am. Chem. Soc. 1998, 120, 1556-1570.

(42) Jungsuttiwong, S.; Limtrakul, J.; Truong, T. N. J. Phys. Chem. B 2005, 109, 13342-13351.

(43) Clark, L. A.; Sierka, M.; Sauer, J. J. Am. Chem. Soc. 2004, 126, 936-947.

(44) Zamaraev, K. I.; Thomas, J. M. Adv. Catal. 1996, 41, 335-358.

(45) Henkelman, G.; Arnaldsson, A.; Jónsson, H. Comput. Mater. Sci. 2006, 36, 354-360.

(46) (a) Kresse, G.; Hafner, J. Phys. Rev. B 1993, 48, 13115-13118.

(b) Kresse, G.; Hafner, J. Phys. Rev. B 1994, 49, 14251-14269.

(c) Kresse, G.; Furthmuller, J. Computat. Mater. Sci. 1996, 6, 15-50.

(d) Kresse, G; Furthmuller, J. Phys. Rev. B 1996, 54, 11169-11186.

(47) Blochl, P. E. Phys. Rev. B 1994, 50, 17953.

(48) Kresse, G.; Joubert, D. Phys. Rev. B 1999, 59, 1758.

(49) Perdew, J. P.; Burke, K.; Ernzerhof, M. Phys. Rev. Lett. 1996, $77,3865-3868$

(50) Ewald, P. Ann. Phys. 1921, 369, 253-287.

(51) Holmes, J. L.; Aubry, C.; Mayer, P. M. J. Phys. Chem. A 1999, 103, 705-709. 
(52) Hunter, E.; Lias, S. J. Phys. Chem. Ref. Data 1998, 27, 413-656.

(53) Pau, J. K.; Kim, J. K.; Caserio, M. C. J. Am. Chem. Soc. 1978, 100, 3831-3837.

(54) Wolf, J. F.; Staley, R. H.; Taagepera, M.; McIver, R. T.; Beauchamp, J. L., Jr.; Taft, R. W. J. Am. Chem. Soc. 1977, 99, 5417-5429.

(55) Benoit, F. M.; Harrison, A. G. J. Am. Chem. Soc. 1977, 99, 3980-3984.

(56) Brand, H. V.; Curtiss, L. A.; Iton, L. E. J. Phys. Chem. 1993, 97, 12773-12782.

(57) http://webbook.nist.gov/chemistry/ (accessed Mar 22, 2011).

(58) Sastre, G.; Katada, N.; Suzuki, K.; Niwa, M. J. Phys. Chem. C 2008, 112, 19293-19301.

(59) Vener, M. V.; Rozanska, X.; Sauer, J. Phys. Chem. Chem. Phys. 2009, 11, 1702-1712. 